\title{
A COMPARATIVE ANALYSIS OF THE INFLUENCE OF LEGISLATIVE HISTORY ON JUDICIAL DECISION-MAKING AND LEGISLATION
}

\author{
Robert G. Vaughn*
}

\section{INTRODUCTION}

Recent Supreme Court opinions often attack the use of legislative history in the interpretation of statutes. ${ }^{1}$ A group of justices, including Justices Scalia, Kennedy, and Thomas, regularly advocate a "plainmeaning" interpretation of statutes. ${ }^{2}$ These justices and other critics propose that the use of legislative history be abandoned or that its relevance be dramatically reduced through the rigorous application of interpretive techniques that rely on the language of statutory provisions. ${ }^{3}$ These attacks coincide with the Supreme Court's declining use of legislative history in the

* A. Allen King Scholar and Professor of Law, Washington College of Law of American University. The author acknowledges David Fenichel for his research assistance. He also thanks his colleagues Candace Kovacic-Fleischer, Egon Guttman, Thomas Sargentich, and Joan Williams for their comments on previous drafts of this article.

1. E.g., Darby v. Cisneros, 509 U.S. 137, 147 (1993) (Chief Justice Rehnquist and Justices Scalia and Thomas refuse to subscribe to portion of majority opinion discussing the implications of legislative history); Public Citizen v. Department of Justice, 491 U.S. 440, 470 (1989) (Kennedy, J., concurring) (arguing that the plain language of the statute should control unless the result is "absurd" even if it would lead to a constitutional issue); Blanchard v. Bergeron, 489 U.S. 87, 99 (1989) (Scalia, J., concurring in part) (commonly used legislative history is unreliable evidence of what members of Congress had in mind when they voted); Pennsylvania v. Union Gas Co., 491 U.S. 1, 30 (1989) (Rehnquist, C.J., Scalia, O'Connor \& Kennedy, JJ., dissenting in part) (rejecting the use of legislative history); United States v. Stuart, 489 U.S. 353, $371-77$ (1989) (Scalia, J., concurring) (arguing that words of the treaty text are controlling).

2. Plain-meaning interpretation relies on the meaning of the words of the statute without the use, or with only limited use, of the legislative history. The appellation "plain-meaning" implies that the language will be given the meaning that is clear, common, or plain. Judge Wald refers to advocates of plain-meaning interpretation as "textualists" and to supporters of the use of legislative history as the "contextualists." Patricia M. Wald, The Sizzling Sleeper: The Use of Legislative History in Construing Statutes in the 1988-89 Term of the United States Supreme Court, 39 AM. U. L. REV. 277 (1990). Plain-meaning interpretation can be literal in that, in defining the meaning of a statutory term, the court will look only to the meaning of those words. Plain-meaning interpretation can also be purposive; that is, the meaning of the words must be determined against the purpose of the statutory provision at issue. As discussed below, a purposive plain-meaning approach can be more difficult to justify. Even the proponents of the use of legislative history assume that interpretation must begin with the words of the statutory provision. Legislative history, however, can inform the choice of meaning to be attached to those words.

3. E.g., Stuart, 489 U.S. at 371-73 (Justice Scalia's comments on the primacy of the words of the statute enacted by Congress); Public Citizen, 491 U.S. at 470 (Kennedy, J., concurring) (arguing that the plain language of the statute should control unless the result is "absurd"); Kenneth W. Starr, Observations about the Use of Legislative History, 1987 DUKE L. J. 371, 374 (expressing reservations about the use of legislative history). 
interpretation of federal statutes ${ }^{4}$ and with increasing academic debate regarding interpretation. ${ }^{5}$

Those who criticize the use of legislative history envision a world in which courts, bound to apply the language enacted by the legislature, lack discretion to roam through legislative history as they seek a basis for an interpretation which is at odds with the statutory language. Plain-meaning interpretation helps to ensure that judges accept their limited role. In this world, legislatures focus on carefully drafting statutory provisions rather than on creating or manipulating the legislative history. This legislative focus reduces interpretive difficulties, saves legislative resources, and emphasizes the importance of the product of the legislative process. In this world, the legislature, courts, and citizens do not expend time or resources organizing or applying a variety of ambiguous-even suspect-legislative materials.

This vision of theory and practice in interpretation reflects arguments and themes that are at least decades ${ }^{6}$ and, in some instances, centuries old. ${ }^{7}$ This vision, however, can be evaluated by exploring how comprehensive

4. Jorge L. Carro \& Andrew R. Brann, Use of Legislative Histories by the United States Supreme Court: A Statistical Analysis, 9 J. LEGIS. 282, 285-90 (1982) (noting increased use of legislative history apart from increase in caseload and impact of tax, social security, civil rights, and antitrust legislation). In recent years, however, the Court's use of legislative history has declined. Stephen Breyer, On The Uses of Legislative History in Interpreting Statutes, 65 S. CAL. L. REV. 845, 846 (1992) (contrasting use of legislative history in almost every statutory construction case in 1981 with no use in 10 of 65 statutory construction cases in the 1989 term and in 19 of 55 cases in the 1990 term).

5. T. Alexander Aleinikoff, Updating Statutory Interpretation, 87 MICH. L. REV. 20 (1988); Breyer, supra note 4; GUIDO CALABRESI, A COMMON LAW FOR THE AGE OF STATUTES (1982); Colin S. Diver, Statutory Interpretation in the Administrative State, $133 \mathrm{U}$. PA. L. REV. 549 (1985); Frank H. Easterbrook, The Role of Original Intent in Statutory Construction, 11 HARV. J.L. \& PUB. POL'Y 59 (1988); William N. Eskridge, The New Textualism, 37 UCLA L. REV. 621 (1990); Daniel A. Farber, Statutory Interpretation and Legislative Supremacy, 78 GEO. L. J. 281 (1989); Earl M. Maltz, Rhetoric and Reality in the Theory of Statutory Interpretation: Underenforcement, Overenforcement, and the Problem of Legislative Supremacy, 71 B.U. L. REV. 767 (1991); Jerry L. Marshaw, Textualism, Constitutionalism, and the Interpretation of Federal Statutes, 32 WM. \& MARY L. REV. 827 (1991); William T. Mayton, Law Among the Pleonasms: The Futility and Aconstitutionality of Legislative History in Statutory Interpretation, 41 EMORY L.J. 113 (1992); Abner J. Mikva, Statutory Interpretation: Getting the Law to Be Less Common, 50 OHIO ST. L.J. 979 (1989); Starr, supra note 3; Cass R. Sunstein, Interpreting Statutes in the Regulatory State, 103 HARV. L. REV. 405 (1989); Wald, supra note 2; Nicholas S. Zeppos, Legislative History and the Interpretation of Statutes: Toward a Fact-Finding Model of Statutory Interpretation, 76 VA. L. REV. 1295 (1990).

6. E.g., Max Radin, Statutory Interpretation, 43 HARV. L. REV. 863 (1930); James Landis, A Note on "Statutory Interpretation," 43 HARV. L. REV. 886 (1930).

7. See Michael Rawlinson, Tax Legislation and the Hansard Rule, 1983 BRT. TAX REV. 274, 275-79 (tracing Hansard rule to 1769); William S. Blatt, The History of Statutory Interpretation: A Study in Form and Substance, 6 CARDOzo L. REV. 799 (1985). 
social legislation would fare in the world of these critics. Such an evaluation emphasizes detailed analysis of specific legislation and uses a comparative approach. This comparative approach avoids the abstract, while permitting general conclusions about whether the critics' vision is valid.

The world of plain-meaning interpretation envisioned by those who criticize the use of legislative history actually exists. The English rules regarding the use of legislative history satisfactorily embody the theory of interpretation required by the critics of current U.S. practice. ${ }^{8}$ An examination of the decisions that interpret the British race and sex discrimination statutes shows how the rejection of legislative history influences judicial decision-making. By comparing these decisions with an available legislative history, it is possible to predict how the use of legislative history could have influenced the outcome of these decisions. The legislative history also allows speculation regarding how the legislative process is affected by the rejection of legislative history. In brief, this comparative analysis permits a look into the world that the critics seek to create.

This world, upon examination, seems far from the paradise envisioned by the critics. It is one in which restrictions on the use of legislative history increase rather than limit the power of judges, often frustrate legislative purpose, hinder rather than improve the legislative process, and restrict the ability of legislative bodies to undertake comprehensive social reform.

For example, the legislative history of the British Race Relations Act of 1976 clearly and unambiguously demonstrates that Parliament included Sikhs within the definition of an "ethnic" group protected by the statute." By relying on a dictionary definition of "ethnic," the Court of Appeal held that Sikhs were not an "ethnic" group. ${ }^{10}$ The House of Lords reversed this decision only after struggling with a variety of dictionary definitions, including an exploration of the etymology of the word. The House of Lords itself devised tests for determining whether groups fell within the statutory definition. ${ }^{11}$

The legislative history of the Race Relations Act of 1976 also demonstrates that Parliament sought an approach to interpretation that was broadly inclusive-one that would reach racial discrimination in all its guises rather than one that would focus on the precise meaning of each term Parliament used to describe the coverage of the statute. ${ }^{12}$ Sikhs were eventually included within the meaning of "ethnic," but the House of Lords' emphasis on the meaning of individual words undoubtedly has caused lower

8. Indeed, some critics see the English rules as the traditional and proper approach to the use of legislative history. E.g., Mayton, supra note 5, at 119.

9. See discussion infra notes 206-09.

10. See infra text accompanying note 86 .

11. See discussion infra notes 87-94.

12. See infra text accompanying notes 210-11. 
courts to exclude groups likely covered by the statute. ${ }^{13}$ It is ironic that Parliament used a broad listing of terms, including "ethnic," in order to avoid a previous House of Lords decision which narrowly construed the term "national origin." 14

The first part of this article argues that the English rules regarding the use of legislative history create the world envisioned by the critics of U.S. practice. It also suggests why the British race and sex discrimination statutes provide a particularly useful body of law with which to evaluate the influence of the rules regarding legislative history. This part concludes by considering two differences between the English and American use of legislative history. These differences, the existence of which might be used as an argument against the use of the parliamentary materials in evaluating the English opinions, result from (1) knowledge of members of Parliament that their deliberations will not be used in the interpretation of statutes, and (2) the variances between American and English legislative processes.

Subsequent sections of the article analyze the judicial decisions under these statutes in light of the rejection of the use of legislative history and predict the effect that the use of the legislative history would have had on those decisions. These sections also speculate on how the refusal to use legislative history has influenced the legislative process.

Generally, the failure to use legislative history has adversely affected the decisions that interpret the sex and race discrimination statutes. Many of these decisions address ambiguities and uncertainties that require appeal to sources beyond the statutory language itself. Neither rules of grammar nor canons of interpretation adequately resolve many of these ambiguities. Indeed, resolution requires an examination of statutory purpose. In the absence of legislative history, interpretation resting on purpose is impoverished and judges are inclined toward more narrow interpretations of statutory provisions. A plain-meaning approach to interpretation can undermine Parliament's broader goals in enacting legislation, and this is especially true when the legislation implements significant social changes.

Adherence to a plain-meaning interpretive approach also increases the discretion of judges. The practice of attaching meaning to words without reference to any source, the similar method of finding purpose, and the ability of judges to select interpretations of language create room for much judicial discretion. Moreover, plain-meaning interpretation draws on societal expectations regarding racial and gender stereotypes that the race and sex discrimination legislation intended to alter. The judges who exercise the discretion inherent in plain-meaning interpretation represent an extremely narrow portion of the English population-a narrow portion with specific 
views and perspectives. This discretion inclines toward more, rather than less, narrow interpretations, especially in the case of the conscientious judge committed to the English rules. Many sets of opinions show the often arbitrary resolution of conflicting interpretations that involve important statutory policies.

Plain-meaning interpretation also fails to account for the ways in which context can modify the meaning of terms. The meaning of a statutory term can never be completely fixed either by reference to a dictionary or by judicial adoption of a definition. Indeed, precedent combined with the absence of legislative history magnifies the weaknesses of plain-meaning interpretation.

The legislative history of the race and sex discrimination statutes is used in this article to explore how it might have affected judicial interpretation. Exploration of the legislative history identifies a number of important judicial decisions that are inconsistent with clear and authoritative legislative history. Also, the legislative history raises serious doubts about other judicial opinions-doubts which are sufficient to require additional justification of these opinions. Finally, the legislative history is helpful in confirming correct but troublesome interpretations.

Most important, perhaps, is that the legislative history includes statements of legislative purpose that could have supported broader judicial construction of the statutes. This history, as the example of the Sikhs illustrates, specifically commends approaches to interpretation different from the plain-meaning approach used by the courts. The examination of the legislative history indicates that, over time, plain-meaning interpretation tends to narrow the scope of the legislation.

An examination of the legislative history also permits informed speculation about the influence that the English rules have had on the legislative process. Generally, the benefits claimed to have accrued to the legislative process by using a plain-meaning interpretive approach-i.e., one which eschews the use of legislative history-are seriously overstated.

Parliament, including parliamentary committees, gave detailed attention to the language of individual clauses of the sex and race discrimination statutes. Still, the legislative history reveals a number of concerns about judicial interpretation as well as considerable criticism of the drafting process. The remarks of government ministers highlight the impossibility of parliamentary compliance with the standards of drafting imposed by the English rules of interpretation. The examination of judicial opinions shows that even careful drafting leaves a large number of interpretive problems. In fact, legislative anxiety about restrictive judicial interpretation motivated efforts at comprehensiveness that obscured, rather than clarified, meaning. Parliamentary deliberations also express frustration with the inability of Parliament to convey to the courts the broader goals and purposes of the legislation. The inability of a legislative body to speak the language 
demanded by plain-meaning interpretation particularly debilitates the drafting and application of social legislation. It is ironic that, in interpreting their own precedent regarding the race and sex legislation, the courts reject an interpretive approach that relies on the specific words chosen and follow one that emphasizes broader readings of policy and purpose.

The article concludes with a brief exploration of the value of its comparative analysis of statutory interpretation. By illuminating the world imagined by the supporters of plain-meaning interpretation, comparative analysis reveals the close relationship between social reform, ideology, and judicial technique.

\section{A WORLD OF JUDICIAL INTERPRETATION WITHOUT LEGISLATIVE HISTORY}

The English rules regarding the use of legislative history satisfy the critics of current U.S. practice by creating a world of judicial interpretation that rarely uses legislative history. The British race and sex discrimination statutes attempt broad social change by protecting women and minorities. These statutes reflect policies similar to ones contained in antidiscrimination provisions in the United States. A significant body of judicial opinions interprets these British statutes.

\section{A. The Use of Legislative History in the Interpretation of Statutes}

The rules regarding the use of legislative history described below were in effect until 1993 and cover the period during which most of the opinions interpreting the race and sex discrimination legislation were issued. In general, these English legal principles eschew reliance on legislative history. A 1993 change in the rules regarding the use of legislative history permits reference to parliamentary debates and committee deliberations in limited circumstances, namely, where the clear statement of a minister responsible for the legislation resolves an ambiguity in the statute. ${ }^{15}$ Decisions subsequent to the change show that it has, thus far, had negligible impact on interpretations of the race and sex discrimination statutes. ${ }^{16}$ The opinions

15. In Pepper v. Hart, [1993] 1 All E.R. 42, 68-69 (H.L.) (opinion of Lord BrowneWilkinson), the House of Lords permitted reference to Hansard and parliamentary material, see infra pp. 9-10, when (1) the legislation is "ambiguous or obscure" or the literal meaning "leads to an absurdity"; (2) the parliamentary material relied upon consists of statements "by a minister or other promoter of the Bill" which, together with other parliamentary material, are necessary to understand the statements and their effect; and (3) "the statements relied on are clear." The House of Lords used the statement of the Financial Minister to resolve in favor of the taxpayer a conflict regarding whether in-house benefits provided to a taxpayer by an employer should be valued at the marginal and not the average cost of the benefit. Id. at 44.

16. Lord Browne-Wilkinson's opinion in Pepper emphasized that parliamentary 
interpreting these statutes, issued between January 1993 and June 1994, have used neither legislative materials nor interpretive techniques different than those discussed below. Therefore, the sample of cases that follows reflects an approach to interpretation severely limiting, and almost excluding, the use of legislative history. In fact, an examination of decisions interpreting these statutes between 1976 and June 1994 shows that, with the exception of a rare reference to a White Paper or an antecedent statute, the decisions do not use any of the legislative history described below.

Legislative history in England is composed of antecedents of the present statutory provision (which include repealed or modified statutes), ${ }^{17}$ pre-parliamentary materials such as "reports of committees and commissions reviewing the existing law and recommending changes, ${ }^{18}$ and parliamentary materials such as texts of the bill as introduced and subsequently amended, committee deliberations, and parliamentary debates. ${ }^{19}$ This history can roughly be divided into antecedents, pre-parliamentary materials, and parliamentary materials.

The parliamentary legislative history contains many of the materials that are thought to be part of the history of congressional deliberations in the United States; but these histories also differ from U.S. congressional

materials should be introduced only in limited circumstances and stated, "[a]ttempts to introduce [legislative history] which does not satisfy [the conditions set out] should be met by orders for costs made against those who have improperly introduced the material." Id. at 67.

The author found no case of the Employment Appeal Tribunal or of the Court of Appeal between January 1993 and June 1994 that referred to Hansard or to other parliamentary material in interpreting the Race and Sex Discrimination Acts. One subsequent decision so narrowly construes the exception which allows the use of legislative history that resort to parliamentary materials may be rare. In R. v. London Borough of Wandsworth ex parte Hawthorne, CO/2122/93 (Q.B. 1994), the court noted that Pepper envisaged "alternative, equally plausible meanings" (a requirement that the court intimated may not have been satisfied in Pepper because a panel in the House of Lords had concluded, four votes to one, that the government's reading was the most plausible-but this was before an enlarged panel using the legislative history reached the rival conclusion). The court said that rival interpretations of clear wording do not create ambiguity and that the exception in Pepper applies only to a "pre-existing" ambiguity. The court also emphasized that the statements must be "ministerial answers, based on advice from officials" and that even ministerial statements must do more than point to an interpretation; they must "conclusively" resolve the ambiguity. The Court of Appeal has suggested that even if the new rule might permit reference to Hansard, reference is foreclosed by precedent that has already interpreted the statutory term at issue. Dawkins v. Department of the Env't, sub nom. Crown Suppliers PSA, 1993 I.R.L.R. 284, 288 (C.A.).

17. RuPERT Cross ET AL., Statutory INTERPRETATION 150 (2d ed. 1987). These materials differ from statutes in pari materia because these statutes are part of the legisiative scheme whereas "legislative history is considered in order to see how a particular provision reached its present position on the statute book." Id. at 150 n.20.

18. Id. at 150 .

19. Id. 
deliberations in some important respects. Committee deliberations consist of transcripts of a committee's discussions; a committee ordinarily issues no committee report. These deliberations take place as part of, rather than as an antecedent to, consideration of the legislation by the full legislative body. Also, hearing records, if any, are much more limited, and pre-parliamentary commissions or committees play a role very similar to that assigned to committee hearings and committee reports in the United States.

In presenting legislation on behalf of the government, those responsible for guiding the legislation through Parliament use departmentally prepared "Notes on Clauses." These Notes on Clauses describe the background of the legislation and explain the purpose and effect of each clause. ${ }^{21}$ These documents, however, are not available outside the government and appear only when they are relied upon in speeches or in answering inquiries regarding the meaning of clauses in the legislation. ${ }^{22}$

The differences between these materials and legislative history in the United States arise partially from the variations between a parliamentary and presidential system. Because the drafting, introduction, and consideration of legislation are in the hands of government ministries, British committee hearings, if any, and deliberations play a different role than they would in a legislative body separate from the executive..$^{23}$

The rules regarding the use of legislative history, although the subject of debate, ${ }^{24}$ significantly limit reliance by the courts on legislative history. No legislative history, either pre-parliamentary or parliamentary, may be used unless there is doubt as to the meaning of legislative language. ${ }^{25}$ This form of the plain-meaning rule considerably obstructs the use of legislative history because the court is permitted to reach an interpretation based on $a$ plain meaning of the statute. ${ }^{26}$ A plain meaning assigns to the statutory words their ordinary usage; it prevails unless the resulting interpretation is

20. Rawlinson, supra note 7 , at 282-83,

21. Id. at 282 (quoting (1969) Law Com. No. 21, Scot. Law Com. No. 11 para 67).

22. Id.

23. S.A. DESMith, Constitutional and AdMINiSTRAtive Law 270 (3d ed. 1980) (describing the differences between congressional and parliamentary committees).

24. A sense of the debate can be found in Lord Renton, The Interpretation of Statutes, 9 J. LEGIS. 252, 255-58 (1982); Rawlinson, supra note 7, at 281-85; CROSS ET AL., supra note 17 , at $157-58$.

25. CROSS ET AL., supra note 17, at 152-53. This "arbitrary exclusion of part of the context . . distinguishes the practice of the English courts with regard to statutory interpretation from that of the courts of the United States and Western Europe." Id. at 153.

26. Id. at 152. "[I]t seems more in accordance with judicial practice to extend [the plain-meaning rule] to cases where the judge is satisfied that one of two or more possible meanings of statutory words, read in a context bereft of their legislative history, best fits the purpose of the legislation." Id. In this sense, the plain-meaning rule becomes a type of reasonable-meaning rule. 
absurd or is, depending on judicial practice, an unreasonable one, plainly at variance with the purpose of the statute as a whole. ${ }^{27}$ If rigorously applied, this form of plain meaning permits the use of legislative history only in limited circumstances.

Even if the court turns to legislative history, the scope of legislative history is limited by the Hansard rule. ${ }^{28}$ This rule prohibits a court from relying on any parliamentary materials, including parliamentary debates, committee discussions, different drafts of the legislation, and other documents generated during parliamentary deliberations. ${ }^{29}$ This rule, reaffirmed after considerable study, ${ }^{30}$ prevents the use of the types of legislative materials often referred to by courts in the United States. ${ }^{31}$ In 1993, the House of Lords created a limited exception to this rule. ${ }^{32}$

Courts may look to legislative antecedents of the statutory provision and to pre-parliamentary materials. Even with pre-parliamentary materials, however, the implications of the Hansard rule restrict their use. Courts may rely on pre-parliamentary materials only to determine the mischief at which the statute is directed but may not rely on this material to determine the

27. Id. at 153 .

28. Id. at 154-58. The rule emerged in 1769 and prevailed in the House of Lords in 1892. Until 1980, at least as to proceedings in the House of Commons, parliamentary privilege prohibited reference in court to Hansard reports of parliamentary deliberations without leave of the House. In 1980, the House of Commons permitted use of Hansard without petition for a number of purposes including as an aid in the interpretation of statutes. In Pepper v. Hart, [1993] 1 All E.R. 42, 67-69 (H.L.), Lord Browne-Wilkinson concluded that reference to the clear statements of ministers would neither infringe Article 9 of the Bill of Rights of 1688 (which prevents the questioning, in any court, of freedom of speech and debate in Parliament) nor violate other constitutional provisions regarding the powers of Parliament and the courts.

29. CROSS ET AL., supra note 17, at 150.

30. Rawlinson, supra note 7, at 281-84.

31. There is a limited exception which allows for the use of portions of parliamentary debates contained in academic treatises. Id. at 282. Lord Denning advised academics to include crucial parliamentary debates in treatises to enable the courts to examine them. Id. (citing Davis v. Johnson, 1979 App. Cas. 264, 276). In the cases interpreting the race and sex discrimination statutes, the author found no case in which parliamentary debates in any form had been used by the Employment Appeal Tribunal, the Court of Appeal, or the House of Lords.

Also, there seems to be a very limited exception when proposed regulations giving effect to a decision of the Court of Justice of the European Community are not subject to any amendment by Parliament or to consideration of amendment in committee. The court may look to Hansard to consider how presentation of the regulations to Parliament formed the basis of its assessment that it would give full effect to the Court of Justice decision. Pickstone v. Freemans PLC, [1988] 2 All E.R. 803, 814-15 (opinion of Lord Templeman). In Pepper, Lord Browne-Wilkinson found little logical ground to distinguish this circumstance from those to which the Hansard rule applied. [1993] I All E.R. at 65.

32. See supra note 15. 
meaning of specific clauses designed to remedy the mischief. ${ }^{33}$ This distinction, difficult to draw and easily ridiculed, ${ }^{34}$ implements the Hansard rule. If the courts were to rely on statements of intention in preparliamentary materials, the prohibition against reliance on these expressions in parliamentary debates, which are more closely related to the legislative process, would become difficult to sustain. ${ }^{35}$

Those who justify restricting the use of legislative history echo many of the arguments made by critics of its use in the United States. ${ }^{36}$ In England, the principal justifications emphasize that the reliance of persons on the language enacted by Parliament requires restrictions on the use of sources outside that language ${ }^{37}$ These justifications also track the concerns of the American critics regarding the accessibility of, ${ }^{38}$ and the cost of reliance on, legislative history. ${ }^{39}$ Not until 1993 did attacks on the Hansard rule, that questioned whether the courts should deny themselves the most useful information regarding the meaning of a statute, ${ }^{40}$ alter even modestly

33. CROSS ET AL., supra note 17, at 159-60.

34. "Bad jokes are then made about the fact that the judges often do gaze into the prohibited areas and say that they have come to their conclusion without being influenced by what they saw there." Id. at 151 .

In Pepper, Lord Browne-Wilkinson stated:

Given the purposive approach to construction now adopted by the courts in order to give effect to the true intentions of the legislature, the fine distinctions between looking for the mischief and looking for the intention in using words to provide the remedy are technical and inappropriate. Clear and unambiguous statements made by ministers in Parliament are as much the background to the enactment of legislation as white papers and parliamentary reports.

[1993] 1 All E.R. at 65.

35. CROSS ET AL., supra note 17 , at $160-61$ (citing Lord Reid in Black-Clawson Int'l Ltd. v. Papierwerke Waldhof-Aschaffenburg, 1975 App. Cas. 591, 614).

36. In Pepper, Lord Browne-Wilkinson, in permitting reference to legislative materials in limited circumstances, stated, "[e]xperience in the United States of America, where legislative history has for many years been much more generally admissible than I am now suggesting, shows how important it is to maintain strict control over the use of such material." [1993] 1 All E.R. at 67.

37. CROSS ET AL., supra note 17 , at 154 . Giving words their ordinary meanings also assures that the statute is interpreted from the perspective of those subject to the law. Lord Browne-Wilkinson has suggested that many statutes are far from comprehensible to the ordinary person and that a risk attending the refusal to use legislative history is that the courts risk subjecting individuals to a law that Parliament never intended to enact. Pepper, [1993] 1 All E.R. at 66 . With the Race and Sex Discrimination Acts, that risk includes denying protection to persons that Parliament intended to protect.

38. Cross ET AL., supra note 17, at 155 (citing Beswick v. Beswick, 1968 App. Cas. $58,74)$. Some commentators believe that, at least in some areas such as tax legislation, readily available indexes of the legislative history exist. Rawlinson, supra note 7, at 288-89.

39. Cross ET AL., supra note 17, at 155 (citing Beswick, 1968 App. Cas. at 74).

40. Rawlinson, supra note 7, at 279 (citing Lord Denning in Davis v. Johnson, 1979 
the traditional rules limiting the use of legislative history. Even suggestions that the legislative history could be relied upon only when the comments of a minister of government directly addressed the interpretive problem at issue were not acted upon until 1993. ${ }^{41}$

In practice, however, courts may use legislative history; and, unfortunately, such use introduces ambiguities. Judges may look to the legislative history more often than the rules permit or published decisions indicate. As to pre-parliamentary materials, some judges, particularly law lords, have participated in committees that recommended legislation. ${ }^{42}$ These judges may find it difficult to disregard their knowledge of a statute's purpose in favor of that knowledge permitted under the rules. Ambiguity increases in those few instances in which law lords sit with the House of Lords in its legislative capacity; ${ }^{43}$ it is conceivable that cases might come

App. Cas. 264, 276). Lord Browne-Wilkinson's opinion in Pepper addresses the principal objections to the use of legislative materials and concludes that they are insufficient to preclude the use of those materials in the circumstances that he sets out. [1993] 1 All E.R. at 62-64. Although legislation consists of words, "[t]his legislation is given legal effect [upon citizens] by virtue of judicial decision, and it is the function of the courts to say what the application of the words used to particular cases or individuals is to be." Id. at 62 (quoting Lord Wilberforce in Black-Clawson Int'1 Ltd. v. Papierwerke Waldhof-Aschaffenburg, [1975] 1 All E.R. 810, 828). The need for legal certainty "demands that the rules by which the citizen is to be bound should be ascertainable by him (or, more realistically, by a competent lawyer advising him) by reference to identifiable sources that are publicly accessible." Id. at 62 (quoting Lord Diplock in Fothergill v. Monarch Airlines Ltd., [1980] 2 All E.R. 696, 705). "Textbooks often include reference to explanations of legislation given by a minister in Parliament, as a result of which lawyers advise their clients taking account of such statements." Id. at 65 . If only limited use is made of legislative materials, the costs of ascertaining them will be reduced. Parliamentary language of necessity can never be completely precise nor anticipate every circumstance in which the language will be applied.

41. Rawlinson, supra note 7, at 287-88.

42. See, e.g., CROSS ET AL., supra note 17, at 151 (citing Lord Hailsham, Addressing the Statute Law, STAT. L. Rrv. 4, 9 (1985)).

43. Mary AnN Glendon et al., Comparative Legal Traditions 525 (2d ed. 1994). These law lords may participate in the debate as long as the topic is not "political." JACKSON'S MACHINERY OF JUSTICE 367 (J.R. Spencer ed., 1989) [hereinafter JACKSON'S MACHINERY]. In the House of Lords debate regarding the 1976 Race Relations Act, a member of the appellate committee who had decided two cases under the 1968 Race Relations Act spoke to the House regarding those decisions. In part, he responded to criticisms that the minister had told Parliament, including the House of Lords, what the 1968 act meant. "But your Lordships' House sitting Judicially, like every other court of law, knew nothing of that." 374 PARL. DEB., H.L. (5th ser.) 548 (Sept. 29, 1976). This statement suggests that, as a convention, a law lord who knew of the debate would approach interpretation as if he or she did not. That a member of the appellate committee, therefore, lacks knowledge of the debate is not the result of being unaware, but is rather the product of the idea that "persons are entitled to guide their lives by what Parliament has said, by the meaning of what is said by Parliament, and not what a Minister says, or even what Parliament means to say." Id. The impact of this idea was well-illustrated on one occasion when the appellate committee's interpretation was supported by the comments of a minister in Parliament. In referring to 
before these law lords which require the interpretation of statutory provisions in the enactment of which they had participated. These practices, although suggesting knowledge of the legislative history outside of the rules, seem unlikely to affect the operation of the rules.

Suggestions, however, that judges do look to the legislative history to inform their decisions, even when they do not rely on that history in their decisions, significantly challenge the rules. If this personal examination occurred frequently, legislative history would inform judicial interpretation even though the articulated basis for a decision would rest upon conventions of language. If so, any correspondence between judicial interpretation and legislative purpose would reflect, not the strengths of English limitations, but the merits of reliance on legislative history-a reliance specifically rejected by the rules. The existing evidence, however, does not support the conclusion that judges often look to legislative history. The supporting evidence consists of statements by one Lord Chancellor, ${ }^{44}$ statements subject to varying interpretations. ${ }^{45}$ However, a number of contradictory statements, ${ }^{46}$ as well as the case law, ${ }^{47}$ are inconsistent with the assumption that the rules regarding the use of legislative history are principally honored

criticism directed toward the committee's interpretation, the above-noted appellate committee member, recognizing that some of the criticism was made by persons who were aware of the minister's comments, called such criticism "mischievous." Id. at 550.

44. Rawlinson, supra note 7, at 280-81. Rawlinson cites instances in which the Lord Chancellor, Lord Hailsham, noted the private reference to Hansard. Although declining to openly rely on it in a decision, Lord Hailsham rather "produced [the interpretation] as an argument of [his] own as if [he] had thought of it [himself]." Id. at 280. In another instance, Lord Denning openly relied on his own examination of Hansard in interpreting a statute. Pepper referred to Lord Denning's use of legislative history in Hadmor Prod. Ltd. v. Hamilton, [1983] 1 App. Cas. 191, and to opposing counsel's argument in the House of Lords that he would have drawn Lord Denning's attention to other passages if he had known Lord Denning were going to rely on the legislative history. [1993] 1 All E.R. at 66.

45. The Lord Chancellor also referred to his own service in Parliament on study commissions. Perhaps his statements should be viewed within the context of his personal experience. Although his reference to similar practices by other judges inclines against such an interpretation, these statements by the Lord Chancellor may also reflect the unique aspects of his position. The Lord Chancellor is a member of the cabinet and, as a result, participates in political life differently than do other judicial officials. JACKSON's MACHINERY, supra note 43 , at 365-66.

46. Rawlinson, supra note 7, at 280 (citing Viscount Dilhorne in his disapproval of surreptitious reference to Hansard); CROSS ET AL., supra note 17, at 158. Lord Hailsham emphasized that if a judge were taken by a "point picked up in private reading," counsel should be allowed to address the point. Id.

47. The literature contains instances where courts reached interpretations of statutes inconsistent with clear statements of intent by government ministers in Parliament. CROSS ET AL., supra note 17, at 157; Rawlinson, supra note 7, at 274 . In this study some similar instances were found. See infra text accompanying notes 206-25. 
in their breach. ${ }^{48}$ Therefore, it is reasonable to conclude that in practice judges do follow the rules restricting examination of legislative history.

Despite some ambiguities introduced by practice, the rules regarding the use of legislative history in England depart substantially from those regarding the use of these materials in the United States. These rules create the world of interpretation envisioned by Justices Scalia, Kennedy, and Thomas, and other critics of the use of legislative history.

\section{B. The Race and Sex Discrimination Acts}

The British race and sex discrimination statutes implement parliamentary goals of social reform. These goals include the protection of women and minorities from discrimination and the alteration of attitudes and practices that engender and sustain that discrimination.

The Sex Discrimination Act of $1975^{49}$ and the Race Relations Act of $1976^{50}$ resulted from White Papers, i.e., governmental studies, issued by a Labour government. ${ }^{51}$ The legislative proposals generated extensive committee consideration in Parliament and passionate, extended debate. ${ }^{52}$ The Acts prohibit direct (disparate treatment) and indirect (disparate impact) discrimination on the basis of race or sex. ${ }^{53}$ The two provisions are closely

48. With judges, as with other public officials, there operates a presumption of regularity. For judges to violate the rules and then hide that violation from the litigants and the public would be both extreme and irregular conduct. That a substantial number of judges engage in such conduct is not to be lightly presumed. Because the evidence for surreptitious use of legislative history is so limited, and the opposing evidence is reasonably strong, a presumption of regularity may not be necessary, but that presumption strengthens the proposition that judges follow the rules regarding the use of legislative materials.

49. Sex Discrimination Act, 1975, ch. 65 (Eng.).

50. Race Relations Act, 1976, ch. 74 (Eng.).

51. See HOME OFFICE, EQUALITY FOR WOMEN, 1974, Cmnd. 5724, at 124; HOME OfFICE, RACIAL DISCRIMINATION, 1975, Cinnd. 6234, at 128. See also DESMITH, supra note 23 , at 431-38 (describing the background of the race and sex discrimination acts); KEITH Hindell, The Genesis of the Race Relations Bill in Policy-Making in Britain (Richard Rose ed., 1969) (discussing the 1968 Race Relations Act). See also Robert N. Covington, Equal Pay Acts: A Survey of Experience Under the British and American Acts, 21 VAND. J. TRANSNAT'L L. 649 (1988) (discussing the antecedent British Equal Pay Act).

52. See DESMITH, supra note 23, at 266-72 (description of the chronology of action taken on a typical piece of legislation). For additional discussion of the legislative history of the two Acts, see infra text accompanying notes 202-05.

53. See generally Robert N. Covington, American and British Employment Discrimination Law: An Introductory Comparative Survey, 10 VAND. J. TRANSNAT'L L. 359 (1977) (discussing the relationship between U.S. and British statutes). This article discusses neither subsequent legislation, such as the 1986 Sex Discrimination Act which was compelled by action of the European Community (EC), nor the role of EC directives on interpretation. For a discussion of these matters, see generally Barry Fitzpatrick, Legislation: The Sex Discrimination Act 1986, 50 MOD. L. REV. 934 (1987) (discussing the 1986 Sex 
related, and decisions regarding one act often refer to the other. ${ }^{54}$

In the United States, race and sex discrimination legislation drew heavily upon similar antidiscrimination provisions. The parliamentary debates are filled with references, both favorable and unfavorable, to the similarity between the British race and sex legislation and the U.S. statutes. ${ }^{55}$ Some comparative studies also illustrate the relationships between the British and American provisions. ${ }^{56}$

The Sex Discrimination Act of 1975 and the Race Relations Act of 1976 form a useful sample with which to test the effects of the English rules that govern the use of legislative history. Both are important provisions. Each features an extensive legislative history, and each has been subject to a large number of judicial interpretations issued over an extended period of time. Their similarity to antidiscrimination statutes in the United States eases analysis and comprehension. Because interpretation of civil rights statutes generated a good part of the Supreme Court's increased reference to legislative history in the $1970 \mathrm{~s},{ }^{57}$ the absence of similar references in the English decisions creates a notable contrast.

Because the British and American statutes address similar social problems, the character of the British decisions is less likely to have been influenced by social, political, or legal circumstances unique to England and

Discrimination Act and the role of EC law). See also JACKSON'S MACHINERY, supra note 43, at 435 .

54. E.g., Tottenham Green Under Fives' Ctr. v. Marshall, 1991 I.R.L.R. 164 (E.A.T.); Greenwich Homeworkers Project v. Mavrou, E.A.T./161/89 (1990); Malik v. Post Office Counters, 1993 I.C.R. 93 (E.A.T.); Patel v. City of Bradford Metro. Council, E.A.T./543/91 (1993); Hertfordshire County Council v. Green, E.A.T./184/91 (1993). The close relationship between the two acts was important in interpreting the immunity provision of the Race Relations Act, an immunity provision that varied from that of the Sex Discrimination Act. See infra text accompanying notes 178-90, 214-23.

55. E.g., 893 PARL. DEB., H.C. (5th ser.) 1449, 1455, 1473, 1480 (June 18, 1975) (concerned with the intrusion of the U.S. E.E.O.C. into private affairs under U.S. legislation); PARl. Deb., H.C., Official RePort, Standing Comm, A 34-35 (Apr. 27, 1976) (U.S. legislation "has probably gone too far in the direction of a crude numerical egalitarianism without relation to skills or ability"); 905 PARL. DEB., H.C. (5th ser.) 1636 (July 8, 1976) (mistake of American law was to go into "undue detail"); id. at 1641 (legislation "slavishly modeled" on U.S. law); id. at 1785 (situation in America was totally different "where the issue was whether people, who were not of the dominant European race, have the same kind of civil legal rights which we take for granted in this country."); 918 PARL. DEB., H.C. (5th ser.) 594 (Oct. 27, 1976) (legislation rests on "presumption that the American experience can be imported here"); 362 PARL. DEB., H.L. (5th ser.) 146 (July 1, 1975) (bill has the "hallmarks . . of the earnest, well-meaning, humourless and puritanical side of the American character.").

56. Covington, supra note 53, app. at 429 (nicely illustrating the similarities); Gerald McGinley, Judicial Approaches to Sex Discrimination in the United States and the United Kingdom-A Comparative Study, 49 MoD. L. REv. 413 (1986).

57. Carro \& Brann, supra note 4, at 285. 
unknown to an American observer. Although a variety of cultural and political factors affects the decisions and interpretations, the similarity of social problems increases confidence that this study will be examining differences significantly attributable to the rules regarding the use of legislative history.

Finally, these Acts have substantial social and political implications. They raise important questions regarding the protection of women and minorities and the use of the law to implement social policy. These types of questions repeatedly confront the courts with issues which require the most sensitive application of the law in complex and difficult circumstances. Judicial interpretation directly affects the efficacy of legislative redress of social inequities.

\section{The Judicial Opinions}

The evaluation of plain-meaning interpretation relies principally on opinions of the Employment Appeal Tribunal, the Court of Appeal, and the House of Lords. The majority of decisions interpreting the Sex Discrimination Act of 1975 and the Race Relations Act of 1976 have been issued by the Employment Appeal Tribunal (E.A.T.). ${ }^{58}$ The Employment Appeal Tribunal is treated as a court of special jurisdiction, ${ }^{59}$ but it has the powers enjoyed by the courts of general jurisdiction. ${ }^{60}$ The Chairman of the E.A.T. enjoys the protected tenure of a judge. ${ }^{61}$ The E.A.T. therefore functions as a judicial body.

The composition of the E.A.T., however, differs from that of a court in that it includes laypersons. ${ }^{62}$ This difference does not affect the judicial character of the body in light of the jurisdiction exercised by the E.A.T. In reviewing the decisions of Employment Tribunals, the E.A.T. may reverse a decision only because the law is misapplied, the relevant statute is misinterpreted, or because the tribunal's decision is one that no reasonable

58. See supra note 54. The Employment Appeal Tribunal operates by panels of three to five persons. General Med. Council v. Goba, 1988 I.R.L.R. 425 (E.A.T.), describes how the E.A.T. will sit in different panels. Unlike the Court of Appeal, one panel of the E.A.T. is not bound by the decisions of another panel.

59. David M. WALKer, The OXfFord COMPANION TO LAW 412 (1980); DESMITH, supra note 23 , at 529-30 (describing specialist courts).

60. DESMITH, supra note 23, at 539. These specialized courts follow the same rules as other courts. The E.A.T. is a superior court of record. Justice Wood, The Employment Appeal Tribunal and Industrial Tribunals: England and Wales, 14 COMMONWEALTH L. BULL. 1479,1483 (1988).

61. The chair of the panel will be a legally qualified judge, normally of the High Court or the Court of Appeal. Wood, supra note 60 , at 1483.

62. The panels, depending on size, normally consist of two to four lay representatives equally divided between employers' and workers' representatives. Id. 
tribunal could reach. ${ }^{63}$ Therefore, its tasks involve review of legal questions, particularly interpretation of the relevant statutes.

The opinions of the E.A.T. reflect this legal emphasis. These opinions focus on questions of law and are often cited in the literature, including in opinions of the Court of Appeal and the House of Lords, that deal with interpretation of the Sex Discrimination Act of 1975 and the Race Relations Act of 1976. The judicial character of these opinions is confirmed by an examination of E.A.T. opinions which interpret the two statutes. Many of these opinions are indistinguishable from those of the Court of Appeal. ${ }^{64}$

\section{Use of Parliamentary Material in Evaluating the Opinions}

Two important differences between British and American legislative history might arguably affect the relevance of the British parliamentary materials to evaluation of the opinions interpreting the race and sex discrimination statutes. These differences principally implicate the predictions of how the use of parliamentary materials would have altered judicial interpretations. They suggest that parliamentary material in England is more likely to alter judicial interpretation than is legislative history in the United States. One difference is that members of Parliament understand that legislative materials will not be used by the courts; the other difference is that the statements of ministers regarding legislation are more authoritative than are similar statements by sponsors of legislation in Congress.

The conclusions regarding the influence of legislative history on judicial interpretation require assessment of what might be called "the paradox of reliance." This paradox suggests that the legislative history of the race and sex discrimination statutes may appear particularly useful and relevant precisely because the participants in the legislative process understood that parliamentary materials would not be used by the courts. If the legislature, as in the United States, knew that the courts would rely on that history, that knowledge could alter the character of the legislative history (e.g., by introducing incentives for manipulation) and reduce its value.

63. John Bowers, The Employment Appeal Tribunal, New L.J. 1083, 1084 (1983). See East Berkshire Health Auth. v. Matadeen, 1992 I.R.L.R. 336, 336 (E.A.T.) (emphasizing that only rarely should E.A.T. interfere with the factual findings of an industrial tribunal). A substantial number of opinions of the E.A.T. issued before June 1994 involve the review of Industrial Tribunal decisions. Challenges to factual determinations (rarely sustained) and to the exercise of discretion by Industrial Tribunals (i.e., whether to waive time limits for filing complaints) are often at issue in review. Indeed, E.A.T. has been criticized for being too legalistic. Linda Dickens, Justice in the Industrial Tribunal System, 17 INDUS. L.J. 58 (1988).

64. This is the author's assessment after reading hundreds of these opinions as well as opinions of the Court of Appeal interpreting these two statutes. 
Therefore, as courts rely more on legislative history, it becomes less useful.

Debatable assumptions about how legislative history is created inhere in the paradox of reliance. Even if the courts were to become an audience for legislative history, it is not clear that the fundamental character of legislative history would vary. If legislative history is the trace of a dynamic and flexible deliberative process, much of the same material would be created whether or not courts rely on it.

Moreover, the argument set forth by the "paradox" forgets that English legislative history, although not directed to courts, is created with an awareness that other audiences will examine it. Historians, academics, and lawyers advising clients can examine and use the legislative history. Perhaps an astute advocate occasionally canvasses the legislative history before making arguments which, without ever referring to that history, rest on language and purpose. The paradox of reliance is strongest if the choice is between access to the legislative history by no one, including the courts, or by everyone. Because English legislative history is created with knowledge that some persons, including legal professionals, will examine that history, the paradox of reliance suggests that judicial availability would, at best, only marginally influence the usefulness of that legislative history.

Thus, the paradox of reliance leads to an absurdity: the most useful legislative history is one which is unavailable. But the opposite is more likely true. As greater reliance is placed on certain types of legislative history, that history becomes more useful and reliable because the legislature recognizes that it will be seen as relevant by the courts. ${ }^{65}$ Once legislative materials are used, even in a limited way, arguments resting on the paradox of reliance lose much of their force. Inquiry then must be directed toward determining how differences in the English and American legislative processes influence the conclusions to be drawn from the analysis of the use of legislative history in England.

The character of the British legislative process affects the value of the legislative history. The executive controls the legislative process in Britain. The executive evaluates legislative proposals, drafts the legislation, and directs its consideration. Therefore, the government and the majority in Parliament speak with a more unified voice than does the Congress in the United States. For this reason, the explanations of the meaning of terms by the responsible government ministers carry a weight and reliability not found

65. Ronald Dworkin describes one type of legislative intent, "institutionalized intention," and gives as an example the uncontradicted statements, given on the floor of Congress by a prominent supporter of a bill, regarding an understanding of what the bill will do. Because Congress understands this to be a legislative convention, it is fair to take these statements as expressing a form of institutionally agreed upon understanding of the legislation. Ronald Dworkin, How to Read the Civil Rights Act, N.Y. REV. BOOKS, Dec. 20, 1979, at 37 43. 


\section{in the comparable statements of any members of Congress. ${ }^{66}$}

Not surprisingly, relaxation of the rules in England prohibiting the use of legislative material has begun by permitting reference to the clear statements of ministers or promoters of legislation that resolve an ambiguity in the statute. ${ }^{67}$ Even assuming that these statements should carry more weight in England than in the United States, the difference in weight does not lessen the negative implications for plain-meaning interpretation. In fact, the clarity of the legislative history starkly highlights the weaknesses of plainmeaning interpretation. Examining the legislative history of the race and sex discrimination statutes also shows that as much would be gained by using other less definitive, but equally helpful, parts of the English legislative history. Therefore, despite the differences in the legislative processes in the two countries, the key lessons to be drawn apply to the advocates of plainmeaning interpretation in the United States as well as in England. These

66. Even in Parliament the statements of ministers regarding the meaning of the legislation can create uncertainties. One uncertainty would arise from the lack of clarity of the statement itself and the ambiguities introduced in the construction of the context against which the statement must be interpreted. Another uncertainty which arises is whether the minister's statement really reflects Parliament's broader understanding of the meaning of the statute. For example, during a discussion in the House of Lords concerning an interpretation of the Court of Appeal which deviated from what the relevant minister had said was the meaning of particular statutory term, a former member of the appellate committee of the House of Lords stated, "[t]he first [great evil] is that if the House of Commons had known that the clubs were outside the $1968 \mathrm{Act}, \mathrm{I}$ am by no means certain that that House might not have wished to amend the Act in that respect." 374 PARL. DEB., H.L. (5th ser.) 550 (Sept. 29, 1976).

Professor William Jordan argues convincingly that differences in the legislative and judicial processes in England and in the United States caution against adoption in the United States of the English rules restricting the use of legislative history. William Jordan, Legislative History and Statutory Interpretation: The Relevance of English Practice, 29 U.S.F. L. REV. 1 (1994). He argues that, because of these differences, the perceived benefits of the English rules might not apply in the United States. He ably details these differences and concludes: "Accordingly, to the extent that the English courts restrict the consideration of legislative history, the context in which they operate is so different from the American context that it is at best misleading to suggest that the English experience supports similar restrictions in the United States." Id. at 42.

His judgment, however, does not foreclose applying to the United States the conclusions of this article (i.e., conclusions regarding Mandla and regarding the influence of the use of legislative history on judicial decision-making and on the legislative process which have been derived from experiments with the English materials). His analysis focuses on whether the perceived benefits of the exclusion of legislative history are sufficient to adopt that rule here. Because he emphasizes the ways in which many of the differences incline toward greater correspondence between parliamentary intention and judicial decisions, his examination supports the conclusions of this article. If significant deviations between judicial decisions and parliamentary intention are created by the absence of legislative history, and if such deviations exist in a system more inclined toward correspondence between the two, then these deviations are more likely in a system, like ours, less constructed to create such correspondence.

67. See discussion supra note 15. 
differences, to be sure, suggest caution in drawing sweeping conclusions about how legislative history in the United. States influences the outcome of judicial decisions. Yet these differences do not reduce the significance of conclusions about how the absence of legislative history would influence the interpretation of these statutory provisions.

The Sex Discrimination Act of 1975 and the Race Relations Act of 1976, along with the opinions interpreting them and the relevant legislative histories, allow an assessment of how comprehensive social legislation would fare in a world in which judicial interpretation occurs without reference to legislative history. The next section uses the opinions interpreting these statutes to evaluate how the restrictions on the use of legislative history influence the character of judicial decisions.

\section{JUDICIAL OPINIONS INTERPRETING THE SEX AND RACE DISCRIMINATION STATUTES}

Judicial opinions interpreting the Race and Sex Discrimination Acts attest to the influence of the rules that restrict the use of legislative history. Because of the English version of the plain-meaning rule, ${ }^{68}$ most opinions make no reference to legislative history. It is usually in references to modified or repealed statutes that legislative history appears in judicial opinions. $^{69}$ No opinion uses parliamentary material, and when the Employment Appeal Tribunal has sought to do so it has been reprimanded. ${ }^{70}$ Given the impact of the Hansard rule on the use of pre-parliamentary legislative history, ${ }^{71}$ few decisions refer to this material, ${ }^{72}$ and some opinions decline to cite it even with respect to the evil at which the statute is directed. ${ }^{73}$ The use of legislative history in these opinions complies with the

68. See supra text accompanying notes 20-27.

69. E.g., Barclays Bank v. James, 1990 I.R.L.R. 90, 92 (E.A.T.) (Equal Pay Act portions repealed by the Sex Discrimination Act of 1975); R. v. Birmingham City Council, 1988 I.R.L.R. 96 (Q.B.) (Education Act of 1944); Garland v. British Rail Engineering Ltd., [1979] 2 All E.R. 1163, 1165-68 (C.A) (background of Sex Discrimination Act).

70. Hampson v. Department of Educ. and Science, 1989 I.R.L.R. 69, 76 (C.A.) (calling "clearly impermissible" the attempt to rely on what happened in relation to a clause as it passed through Parliament).

71. See supra text accompanying notes 33-35.

72. E.g., Hampson v. Department of Educ. and Science, [1990] 2 All E.R. 513, 520 (H.L.) (referring to appellant's argument based on the White Paper on Racial Discrimination); Enderby v. Frenchay Health Auth., 1991 I.R.L.R. 44, 49 (E.A.T.) (White Paper on Racial Discrimination cited for inclusion of disparate impact discrimination in the Sex Discrimination Bill based on Griggs v. Duke Power Co.).

73. E.g., General Med. Council v. Goba, 1988 I.R.L.R. 425, 429 (E.A.T.) (not necessary to quote from the White Paper on Racial Discrimination because the "purposes and intentions of the [Act] are clear and well established"). The infrequent reference to White Papers by the courts contrasts with the more frequent discussion of them in the parliamentary 
pre-1993, more restrictive English rules regarding such use.

Not surprisingly, the rejection of legislative history emphasizes the meaning of individual words and phrases. The opinions stress that words are to be given their "ordinary," "usual," or "common" meaning. ${ }^{74}$ Some opinions assert that a word cannot be given more than its ordinary meaning. ${ }^{75}$ Because of the centrality of individual terms and phrases, some opinions decry shorthand summaries of statutory terms. These opinions fear that definitions of the shorthand summaries will emerge and that development of the statutory language will not occur. ${ }^{76}$ Even words broadly descriptive of a body of interpretation are to be shunned in preference for the specific statutory terms. ${ }^{n}$

debates. E.g., 906 PARL. Deb., H.C. (5th ser.) 1547, 1551, 1560, 1566, 1606, 1632 (Mar. 4, 1976); id. at 1857 (July 8, 1976); id. at 569 (Oct. 27, 1976) (White Paper played important role in the debate.). The judicial reluctance to rely on White Papers may reflect the limitations imposed by the Hansard rule as well as a concern that a comparison of White Papers with the final legislation, while at the same time ignoring the legislative deliberations, could mislead courts as to the intent of Parliament. E.g., id. at 1651 (July 8, 1976) (discussion of rejection by the White Paper on Racial Discrimination of requirement that every government contractor report its employment policies to the government); 893 PARL. DEB., H.C. (5th ser.) 1584 (June 18, 1975) (discussion of the position of the White Paper on Sex Discrimination of restrictive work rules designed to protect women workers); 906 PARL. DEB., H.C. (5th ser.) 1560 (Mar. 4, 1976) (funding of community relations left open by the White Paper); $i d$. at 1566 (question of criminal liability left open).

74. E.g., Leverton v. Clwyd County Council, [1989] 2 W.L.R. 47, 72 (H.L.) (opinion of Lord Bridge referring to the language of Subsection 1(6) as "clear and unambiguous"); Malik v. Post Office Counters, 1993 I.C.R. 93, 97 (E.A.T.) (words to be given their ordinary meaning); Home Office v. Holmes, 1984 I.R.L.R. 299, 301 (E.A.T.) ("It appears to us that words like 'requirement' and 'condition' are plain, clear words of wide import fully capable of including any obligation of service whether full or part time ....").

75. Malik v. Post Office Counters, 1993 I.C.R. 93, 97-98 (E.A.T.) (broader meaning "not there on the face of the section" and not a question of "narrowly construing the section in rejecting the argument advanced but rather of declining to read in what is suggested should be implied"); Ojutiku v. Manpower Services Comm'n, 1992 I.R.L.R. 418, 421-22 (E.A.T.) (opinion of Lord Justice Kerr); Kingston \& Richmond Area Health Auth. v. Kaur, 1981 I.R.L.R. 337, 339 (E.A.T.) ("but our function is solely to administer the law").

76. E.g., Ojutiku v. Manpower Services Comm'n, 1992 I.R.L.R. 418, 421 (C.A.) (opinion of Lord Justice Eveleigh):

I am very hesitant to suggest another expression for that which is used in the statute, for fear that it will be picked up and quoted in other cases and then built upon thereafter, with the result that at the end of the day there is a danger of us all departing far from the meaning of the word in the statute.

Id.

77. E.g., Strathclyde Regional Council v. Porcelli, 1986 I.R.L.R. 134, 140 (C.A.) (opinion of Lord Grieve) (Sexual harassment is a term not used in the statute and should be avoided in describing coverage of the Act.); Wadman v. Carpenter Farrer Partnership, 1993 I.R.L.R. 374, 377 (E.A.T.) (“' 'SS exual harassment' is not a definitive phrase in law."). But see Bracebridge Engineering Ltd. v. Darby, 1990 I.R.L.R. 3, 4 (E.A.T.), in which the Shorter Oxford English Dictionary definition of "sexual harassment" was used in addressing 
The source of the meaning of statutory terms is less clear. Many opinions derive the "ordinary" meaning of terms without reference to any source, as if the meaning were self-evident. ${ }^{78}$ This lack of reference could reflect reliance on the judge's own view of what the words mean. Reliance on individual conceptions of words introduces elements of subjectivity that are inconsistent with many of the justifications for relying on the words alone. This subjectivity threatens the view that judges are simply translating the meaning of the words chosen by the legislature. For example, the judge's examination of the language takes place in a context in which the meaning given to the word influences the outcome of a specific dispute already framed for resolution. This context could alter the way in which the judge perceives the meaning of the words. In addition, a failure to reference any source when determining the meaning of statutory terms does not necessarily demonstrate that the judge has not consulted a source. The judge could have examined sources to determine the meaning of the word but simply not cited those sources.

Dictionaries are the most commonly cited sources for the meaning of words. ${ }^{79}$ Opinions frequently contain references to a variety of dictionaries.

the coverage of the sex discrimination statute.

78. E.g., Francis v. British Airways Engineering Overhaul, Lid. 1982 I.R.L.R. 10, 12 (E.A.T.) ("requirement"); The Record Production Chapel v. Turnbull, E.A.T./955/83 (1984) (transcript) ("qualifying body"); The Home Office v. Holmes, 1984 I.R.L.R. 299, 300 (E.A.T.) ("requirement" or "condition"); Jeremiah v. Ministry of Defence, 1979 I.R.L.R. 436, 437-38 (C.A.) ("detriment"); James v. Eastleigh Borough Council, [1989] 3 W.L.R. 123, 127 (C.A.) ("section of the public"); London Borough of Barking \& Dagenham v. Camara, 1988 I.R.L.R. 373, 376 (E.A.T.) ("requirement" or "condition" must apply to the job and not a personal characteristic of applicant); Garland v. British Rail Engineering Ltd., [1979] 2 All E.R. 1163, 1166 (C.A.) ("provision in relation to death or retirement"); Clymo v. Wandsworth London Borough Council, 1989 I.R.L.R. 241, 246-47 (E.A.T.) ("detriment"); Lambeth London Borough Council v. Commission for Racial Equal., 1989 I.C.R. 641, 646-47 (E.A.T.) ("personal service"). The Court of Appeal decision in Lambeth referred to the Oxford English Dictionary to define "personal." Lambeth London Borough Council v. Commission for Racial Equal., 1990 I.C.R. 768, 775 (C.A.).

79. E.g., Lambeth London Borough Council v. Commission for Racial Equal., 1990 I.C.R. 768, 775 (C.A.) ("personal" from the Oxford English Dictionary); James v. Eastleigh Borough Council, [1990] 2 All E.R. 607, 620 (H.L.) (Lord Lowry used the Oxford English Dictionary for "ground" and for the "dictionary definition" of "discriminate"); Commission for Racial Equal. v. Dutton, [1989] 2 W.L.R. 17, 22-23 (C.A.) (Chambers 20th Century Dictionary, Supplement to Oxford English Dictionary, Longman Dictionary of Contemporary English, and Oxford English Dictionary defining "gypsy"-a term used in other statutory provisions applicable to race relations act); Singh v. Rowntree Mackintosh, Ltd., 1979 I.R.L.R. 199, 200 (E.A.T.) ("justifiable" from the Shorter Oxford English Dictionary); Ojutiku v. Manpower Services Comm'n, 1982 I.R.L.R. 418, 422 (C.A.) ("justifiable" from "dictionary definitions"); Mandla v. Dowell Lee, 1983 I.R.L.R. 209, 211 (H.L.) ("ethnic" from three dictionaries); Clymo v. Wandsworth London Borough Council, 1989 I.R.L.R. 241. 248 (E.A.T.) ("can" from the Shorter Oxford English Dictionary); Greencroft Soc. Club and Inst. v. Mullen 1985 I.C.R. 796, 802 (E.A.T.) (Shorter English Oxford Dictionary indicating 
In addition, judges occasionally examine the etymology of words. ${ }^{80}$ Indeed, references to more than one dictionary in a single opinion are not unknown. ${ }^{81}$ These references highlight that words can have several meanings and that dictionaries can disagree on the priority of these meanings. These exercises involving dictionaries also demonstrate that words have different meanings depending upon the context in which they are used. ${ }^{82}$

The opinion of Lord Fraser in Mandla $v$. Dowell Lee $e^{83}$ illustrates many of the observations previously made. In Mandla, the House of Lords addressed the exclusion of a Sikh from a private school. The Sikh student was prohibited by the school from wearing a turban required by Sikh tradition. ${ }^{84}$ As a part of his claim under the Race Relations Act of 1976, the student argued that he was a member of a "racial group" that "could not comply" with the no-turban rule. The Act defined racial group as "a group of persons defined by reference to colour, race, nationality or ethnic or national origins." 85 The Court of Appeal, relying on the definition of "ethnic" contained in the Concise Oxford English Dictionary (1934 edition), i.e., "pertaining to race," held that Sikhs were essentially a religious group who shared racial characteristics with other religious groups, including

that the term "nil" "is part of a ratio" and denotes not being part of a whole). Although relying on the dictionary to help define the term "in pursuance of," Lord Lowry in Hampson v. Department of Educ. and Science, [1990] 2 All E.R. 513, 518 (H.L.), expressed some reservations: "A dictionary is not by itself the most reliable guide to statutory interpretation, but it serves to remind us of the commonly accepted meaning of pursuance as pursuit, the action of following out a process or the action of proceeding in accordance with a plan, direction, or order." Id.

80. E.g., in Mandla, Lord Fraser noted that the word "ethnic" is of Greek origin:

[B]eing derived from the Greek word 'ethnos' the basic meaning of which appears to have been simply 'a group' not limited by reference to racial or other distinguishing characteristics. . . . I do not suggest that the meaning of the English word in a modern statute ought to be governed by the meaning of the Greek word from which it is derived, but the fact that the meaning of the latter was wide avoids one possible limitation on the meaning of the English word.

1983 I.R.L.R. at 212.

81. E.g., id. at 211; Commission for Racial Equal. v. Dutton, [1989] 2 W.L.R. 17, 2223 (C.A.).

82. See infra text accompanying notes 132-38 (discussing how context can alter the meaning of "can comply"); see also Dutton, 1989 I.R.L.R. at 13 (Same word in different statutes can have a "wholly and totally different meaning assigned to it."); R. v. Birmingham City Council, 1988 I.R.L.R. 96, 99 (Q.B.) ("Ground" should be construed in context.).

83. Mandla, 1983 I.R.L.R. at 210-14.

84. Mandla v. Dowell Lee, 1983 I.R.L.R. 17 (C.A.). The school believed that the wearing of the turban would accentuate religious and social distinctions in the school. The school's student body was multiracial and was predominantly Christian in faith. Id. at 22 .

85. Race Relations Act, 1976, ch. 74, § 3(1) (Eng.). 
Hindus and Muslims, living in the Punjab. ${ }^{86}$ As such, Sikhs were not a racial group protected by the Act.

The opinion of Lord Fraser in the House of Lords discusses the definition of the word "ethnic." The definition is contained in different dictionaries: The Concise Oxford English Dictionary, mentioned above; The Oxford English Dictionary (1897 edition), which contains a definition similar to the one listed in The Concise Oxford English Dictionary; and the Oxford English Dictionary (1972 edition) which defines "ethnic" as "pertaining to or having common racial, cultural, religious, or linguistic characteristics, especially designating a racial or other group within a larger system." 87 Lord Fraser rejected all three definitions. In rejecting those contained in the Concise English Oxford Dictionary and in the Oxford English Dictionary (1987 edition), he noted that "it is clear Parliament must have used the word in some more popular sense." 88 The definition found in the Oxford English Dictionary (1972 edition) was also rejected because it was "too loose and vague to be accepted as it stands." ${ }^{89}$ Yet he found in this definition, together with the Greek origin of the word "ethnic," sufficient evidence to justify a broad meaning of the word-a meaning "consistent with the experience of those who read newspapers at the present day." 90 He also relied on an opinion of the Court of Appeal of New Zealand which interpreted the same word in a statute that was designed to prohibit incitement of ill-will on ethnic grounds. Lord Fraser stated that "[i]t is important that courts in Englishspeaking countries should, if possible, construe the words which we are considering in the same way where they occur in the same context." 91

After rejecting all the definitions, Lord Fraser articulated some seven factors, two of which "appear[ed] to [him] to be essential" in distinguishing one ethnic group from another. ${ }^{92}$ In his view, the meaning of "ethnic" rests

86. Mandla, 1983 I.R.L.R. at 20.

87. Mandla, 1983 I.R.L.R. at 211 (emphasis added).

88. Id. A definition tied solely to race would create considerable difficulty. Distinctive biological characteristics of a race would be difficult to establish because very few distinctions "are scientifically recognized as racial." Id.

89. Id. 'But in seeking for the true meaning of 'ethnic' in the statute, we are not tied to the precise definition in any dictionary." Id. In a separate opinion, Lord Templeman stated, "The true construction of the expression 'ethnic origins' must be deduced from the [1976] Act." Id. at 214.

90. Id. at 211. For Lord Fraser's discussion of the word "ethnic," see supra note 80. In the House of Lords debate on the Race Relations Act of 1976, one member critical of the inclusion of the term "ethnic" in the legislation cited the definition contained in the Oxford English Dictionary (1972 edition) (definition cited above). 374 PARL. DEB., H.L. (5th ser.) 70 (Sept. 27, 1976). Another referred to the Greek derivation of the term to the effect that the term was unclear and added little. Id. at 74.

91. Mandla, 1983 I.R.L.R. at 212 (referring to King-Ansell v. Police, [1979] 2 N.Z.L.R. 531 (C.A.)).

92. Mandla, 1983 I.R.L.R. at 211. These conditions include: 
on " $[t]$ he real test ... whether the individuals or the group regard themselves and are regarded by others in the community as having a particular historical identity in terms of their colour or their racial, national or ethnic origins." 93 On this basis, he concluded that Sikhs were an ethnic group under the Act. ${ }^{94}$

Lord Fraser's opinion not only illustrates the reliance on the definition of specific terms but also demonstrates the ambiguities and uncertainties that require appeal to sources beyond the text itself. A complicated statute of necessity contains ambiguities and raises issues that the language of the statute does not specifically address. When words have more than one meaning, when dictionaries disagree, and when the interpretation presents choices not resolved by the specific language of the statute, opinions turn to some other basis for defining statutory terms.

Some opinions choose between equally plausible "plain-meaning" interpretations by using rules of grammar or other conventions of interpretation. ${ }^{95}$ Examples found in the opinions include such inconsistent

1) a long shared history, of which the group is conscious as distinguishing it from other groups, and the memory of which it keeps alive; 2) a cultural tradition of its own, including family and social customs and manners, often but not necessarily associated with religious observance . . . ; 3) a common geographical origin, or descent from a small number of common ancestors; 4) a common language, not necessarily peculiar to the group; 5) a common literature peculiar to the group; 6) a common religion different from that of neighbouring groups or from the general community surrounding it; 7) being a minority or being oppressed or a dominant group within a larger community.

Id. The first two conditions Lord Fraser saw as "essential," the remaining five as "relevant." Id. Lord Templeman articulated the considerations defining an ethnic group by stating that "[i]n my opinion, for the purposes of the [1976] Race Relations Act a group of persons defined by reference to ethnic origins must possess some of the characteristics of a race, namely group descent, a group of geographical origin and a group history." Id. at 214.

93. Id. at 212 (quoting Justice Richardson in King-Ansell v. Police, [1979] 2 N.Z.L.R. $531,542)$.

94. Gwynedd County Council v. Jones, E.A.T. 554/85 (1986), illustrates how subsequent decisions turn on these factors. Applying these factors articulated in Mandla, courts have disagreed as to whether Rastafarians are an ethnic group. See Dawkins v. Department of the Env't, 1993 I.R.L.R. 284, 288 (C.A.) (Rastafarians held not to be a separate ethnic group).

95. E.g., opinions relying on grammar: Clymo v. Wandsworth London Borough Council, 1989 I.R.L.R. 241, 246 (E.A.T.) ("'[S]ubjecting' is an active verb."); James v. Eastleigh Borough Council, [1990] 2 All E.R. 607, 619 (H.L.) (Key words are "an adverbial clause modifying the transitive verb.") (opinion of Lord Lowry). E.g., opinions relying on conventions of interpretation: Hampson v. Department of Educ. and Science, 1989 I.R.L.R. 69, 79 (C.A.) (narrow construction) (opinion of Parker, L.J.); Brennan v. J.H. Dewhurst Ltd., 1983 I.R.L.R. 357, 359-60 (E.A.T.) (seeking to avoid gaps in legislation); Ojutiku v. Manpower Services Comm'n, 1982 I.R.L.R. 418, 421-22 (C.A.) (adherence to ordinary meaning of words); Lambeth London Borough Council v. Commission for Racial Equal., 1990 
precepts as the following: broadly interpreting the act, ${ }^{96}$ narrowly interpreting the act, ${ }^{97}$ interpreting the language to avoid a gap in the coverage of the statute,,$^{98}$ adhering to the ordinary meaning of the statute even if this creates a gap in the application of the statute, ${ }^{99}$ narrowly construing exceptions, ${ }^{100}$ not construing exceptions so narrowly that the intent of Parliament is violated, ${ }^{101}$ reading a general term in a series as limited by other words in the series, ${ }^{102}$ and reading a general term in a series as not necessarily limited by the more narrow terms proceeding it. ${ }^{103}$ Sometimes reliance on such conventions is articulated; sometimes it is not. The examples, that recall a well-known article by Karl Llewellyn contrasting similarly inconsistent conventions in the United States, ${ }^{104}$ suggest that the choice between meanings cannot be automatically resolved by invoking these conventions.

Many of the choices between competing interpretations are made by viewing the specific language in the context of the statute as a whole. This approach requires examining the relationship between the language in one section and in other sections of the Act. ${ }^{105}$ It also requires exploring

I.C.R. 768, 770, 777 (C.A.) (exceptions to be narrowly construed); Tottenham Greens Under Fives' Ctr. v. Marshall, 1989 I.R.L.R. 147, 149 (E.A.T.) (words not to be narrowly construed when containing expressions of wide scope); De Souza v. Auto. Ass'n, 1985 I.R.L.R. 87, 89 (E.A.T.) (ejusdem generis).

96. E.g., Weaver v. National Ass'n of Teachers in Further and Higher Educ., 1988 I.C.R. 599, 603 (E.A.T.) ("The policy of the Acts is to take a broad approach . . . so as to encompass a wide range of cases so that sex discrimination and race discrimination can be eliminated.").

97. E.g., Meer v. London Borough of Tower Hamlets, 1988 I.R.L.R. 399, 403 (C.A.) (Broad interpretation can have capricious effects.) (opinion of Staughton, L.J.). The cases discussed supra note 78 also opt for a narrow interpretation on the grounds that the courts cannot expand the meanings of words beyond their "ordinary" meanings.

98. E.g., Brennan v. J.H. Dewhurst Lid., 1983 I.R.L.R. 357, 359-60 (E.A.T.).

99. E.g., Ojutiku v. Manpower Services Comm'n, 1982 I.R.L.R. 418, 421 (C.A.).

100. E.g., Lambeth London Borough Council v. Commission for Racial Equal., 1990 I.C.R. 768, 777 (C.A.).

101. E.g., Tottenham Green Under Fives' Ctr. v. Marshall, 1991 I.R.L.R. 162, 165 (E.A.T.).

102. E.g., De Souza v. Auto. Ass'n, 1985 I.R.L.R. 87, 88 (E.A.T.). The Court of Appeal agreed that a racial insult may not be a "detriment" even if it caused distress. De Souza v. Auto. Ass'n, 1986 I.R.L.R. 103, 107 (C.A.).

103. E.g., Jeremiah v. Ministry of Defence, 1979 I.R.L.R. 436, 438 (C.A.).

104. Karl N. Llewellyn, Canons of Construction, 3 VAND. L. REV. 395 (1950).

105. E.g., Webb v. E.M.O. Air Cargo (U.K.) Lid., 1993 I.R.L.R. 27, 29 (H.L.) (relationship between sections 5(3) and 2(2) of the Sex Discrimination Act); Barclays Bank PLC v. Kapur, 1989 I.R.L.R. 57, 60 (E.A.T.) (comparing sections 5 and 7 of the Race Relations Act and the relationship between sections 54, 57, and 68); General Med. Council v. Goba, 1988 I.R.L.R. 425, 427 (E.A.T.) (comparing sections 13 and 41 of the Race Relations Act of 1976); Tottenham Green Under Fives' Ctr. v. Marshall, 1989 I.R.L.R. 147, 148 (E.A.T.) (contrasting sections 4 and 5 of the Race Relations Act of 1976); James v. 
implications with respect to the operation of the statute as a whole and the consequences of varying interpretations of the language. ${ }^{106}$

From among interpretations permitted by the language, the opinions are willing to choose those interpretations that best implement the purpose, goal, or policy of the statute. ${ }^{107}$ Sometimes the articulations of purpose are central to the interpretation; ${ }^{108}$ at other times, references to purpose seem extraneous to a decision already reached on other grounds. ${ }^{109}$ Still, the opinions often refer to the purpose of either the Acts or particular portions of the Acts. As these decisions demonstrate, to the extent that it seeks to avoid reference to purpose, plain-meaning interpretation has failed.

Judges derive the purpose of the statute in a number of ways. Sometimes they find purpose in the language of the Acts, including the long titles and the preambles. ${ }^{110}$ In addition, judges deduce the purpose or purposes to be served from the language of specific provisions. ${ }^{11}$ The interpretations of executive agencies ${ }^{12}$ or even U.S. precedent ${ }^{113}$ on related

Eastleigh Borough Council, 1989 I.R.L.R. 318, 321 (C.A.) (Interpretation of 1(1)(a) of the Sex Discrimination Act of 1975 would render 1(1)(b) superfluous.); R. v. Birmingham City Council, 1988 I.R.L.R. 96, 99 (Q.B.) (comparison of sections 1(1)(b) and 66(3)); Brennan v. J.H. Dewhurst Ltd., 1983 I.R.L.R. 357, 359 (E.A.T.) (comparison of subparts of section 6(1) of the Sex Discrimination Act of 1975).

106. E.g., Timex Corp. v. Hodgson, 1981 I.R.L.R. 530, 532 (E.A.T.) (Interpretation of genuine occupational qualification would have "startling consequences" which would limit employer options, would not lead to evasion, and in case of doubt one "should lean heavily against" the interpretation.); R. v. Birmingham City Council, 1988 I.R.L.R. 96, 98 (Q.B.) (Interpretation would undercut the structure of the Sex Discrimination Act of 1975.); Wallace v. South Eastern Educ. and Library Bd., 1980 I.R.L.R. 193, 195 (N. Ir. C.A.).

107. See cases cited infra notes 108-16.

108. E.g., Tottenham Green Under Fives' Ctr. v. Marshall, 1989 I.R.L.R. 147 (E.A.T.).

109. E.g., General Med. Council v. Goba, 1988 I.R.L.R. 425 (E.A.T.).

110. E.g., purpose derived from long title: Brennan v. J.H. Dewhurst Ltd., 1983 I.R.L.R. 357, 360 (E.A.T.); Lambeth London Borough Council v. Commission for Racial Equal., 1990 I.C.R. 768, 774 (C.A.); Mandla v. Dowell Lee, 1983 I.R.L.R. 209, 210 (H.L.) (opinion of Lord Fraser); purpose derived from preamble: $\mathrm{R}$ v. Birmingham City Council, 1988 I.R.L.R. 96, 99 (Q.B.).

111. E.g., Brennan v. J.H. Dewhurst Ltd., 1983 I.R.L.R. 357, 359-60 (E.A.T.) (detailed analysis of section 6 of the Sex Discrimination Act of 1975 to obtain its purpose); Barclays Bank PLC v. Kapur, 1989 I.R.L.R. 57, 61 (E.A.T.) (Section 4(2)(c) of Race Relations Act interpreted in light of language of section 4(2)(a),(b).).

112. E.g., Garland v. British Rail Engineering Ltd., [1979] 2 All E.R. 1163, 1166 (opinion of Lord Denning) (Equal Opportunities Commission).

113. E.g., Enderby v. Frenchay Health Auth., 1992 I.R.L.R. 15 (C.A.) (relying on Griggs v. Duke Power, 401 U.S. 424 (1971), and other precedents including Wards Cove Packing Co., Inc. v. Atonio, 109 S. Ct. 2115 (1989)). The Court of Appeal, likewise, found that the origins of indirect discrimination were in Griggs. Enderby v. Frenchay Health Auth., 1992 I.R.L.R. 15, 20 (C.A.); Watches of Switzerland Ltd. v. Savell, 1983 I.R.L.R. 141, 146 (E.A.T.) (looking to Griggs and citing Clarke v. Eley (I.M.I.) Kynoch Ltd., 1982 I.R.L.R. 482, 485 (E.A.T.); Perera v. Civil Serv. Comm'n, 1983 I.R.L.R. 166, 170 (C.A.) (origin of 
provisions also allow a court to articulate the purpose of provisions. More commonly, opinions determine the purpose of the statutes without stating any basis for the determination. ${ }^{114}$ The failure of the Employment Appeal Tribunal to support its determinations of purpose may be due in part to the Tribunal's specialized character and its familiarity with these Acts. ${ }^{115}$ But regardless of how they are derived, many statements of statutory purpose are

indirect discrimination in "the United States and decisions there").

Some courts have rejected U.S. precedent in determining purpose because U.S. law did not contain a provision analogous to the one being interpreted. See, e.g., Hampson v. Department of Educ. and Science, 1989 I.R.L.R. 69, 75 (C.A.); Ojutiku v. Manpower Services Comm'n, 1982 I.R.L.R. 418, 422 (C.A.); Cox v. Kraft Foods Ltd., E.A.T./281/82 (1983) (transcript).

It is ironic that the Griggs decision has been criticized for misreading the legislative history of Title VII in creating recovery for discrimination resulting from adverse impact. See Michael Gold, Griggs' Folly: An Essay on the Theory, Problems and Origin of the Adverse Impact Definition of Employment Discrimination and a Recommendation for Reform, 7 INDUS. REL. L.J. 429, 520-23 (1985).

114. E.g., Clymo v. Wandsworth London Borough Council, 1989 I.R.L.R. 241, 248 (E.A.T.) (regarding limited definition of "can comply," "[s]uch a construction appears to us to be wholly out of sympathy with the spirit and intent of the Act."); Tower Hamlets London Borough Council v. Rabin, 1989 I.C.R. 693 (E.A.T.) (purpose of the Race Relations Act not to remove religious intolerance); Tottenham Green Under Fives' Ctr. v. Marshall, 1989 I.R.L.R. 147, 149 (E.A.T.) ("[T]he purpose of the Act is to eliminate discrimination" but not to prevent attempts to integrate.); Greencroft Soc. Club and Inst. v. Mullen, 1985 I.C.R. 796, 802 (E.A.T.) (The interpretation of proportion excluding nil "would, in our view, run counter to the whole spirit and purpose of the sex discrimination legislation."); Clarke v. Eley (I.M.I.) Kynoch Ltd., 1982 I.R.L.R. 482, 485 (E.A.T.) ("The purpose of . . . the legislature in introducing the concept of indirect discrimination into the 1975 [Sex Discrimination] Act and the Race Relations Act [of] 1976 was to seek to eliminate those practices which had a disproportionate impact on women or ethnic minorities and were not justifiable for other reasons."); General Med. Council v. Goba, 1988 I.R.L.R. 425, 429 (E.A.T.) (purposes and intentions of the Race Relations Act well established); R. v. Birmingham City Council, 1988 I.R.L.R. 96, 98 (Q.B.) ("I do not think that it was the intention of Parliament that those who have to consider these matters of discrimination [confront an unnecessarily complicated procedure]."); Home Office v. Holmes, 1984 I.R.L.R. 299, 301 (E.A.T.) ("The scheme of the [1975 Sex Discrimination Act] involves casting a wide net."); Adekeye v. The Post Office, 1993 I.R.L.R. 324, 325 (E.A.T.) ("[I]t seems to us that the mischief which Parliament was intending to cover by those provisions was that of a person finding himself out of a job because of racial or other discriminatory grounds. ${ }^{n}$ ).

Statements of purpose can reflect a variety of views:

The Sex Discrimination Act of 1975 was not, in my judgment, designed to provide a basis for capricious and empty complaints of differentiation between the sexes. Nor was it intended to operate as a statutory abolition of every instinct of chivalry and consideration on the part of men for the opposite sex.

Stoke-on-Trent Community Transport v. Cresswell, E.A.T./359/93 (1993) (transcript) (quoting Automotive Products Ltd. v. Peake, 1977 I.C.R. 968, 973).

115. See supra text accompanying notes 58-64. 
extremely broad, ${ }^{116}$ presenting propositions with which few persons could disagree. Reliance on purpose when interpreting statutory provisions, however, undercuts the rules that limit reference to legislative history. ${ }^{117}$

The actions and statements of the legislature are principal, if not controlling, in establishing purpose; and the opinions demonstrate the difficulty of relying on purpose without the use of legislative history. Such difficulty is apparent when English courts use U.S. opinions in order to determine the purpose of the British statutes. Yet English courts, in using these U.S. opinions that interpret the purpose of U.S. laws by drawing on Congressional materials, simultaneously refuse to examine any parliamentary materials directly addressing those statutory purposes. Such reliance on U.S. decisions to establish statutory purpose seems ironic, if not somewhat bizarre.

Rarely do the opinions recognize the potential conflicts between an interpretation resting on purpose and one relying on the ordinary meaning of words ${ }^{118}$ or that purpose can suggest meanings not within the original choices presented by the language. Few opinions express a willingness to rely on purpose. Without this willingness, a court has more difficulty abandoning what, in its view, is the most common meaning of a word. ${ }^{119}$

116. E.g., General Med. Council v. Goba, 1988 I.R.L.R. 425, 429 (E.A.T.) (Purpose is "to give personal rights not to be discriminated against on racial grounds nor to be victimized."); Barclays Bank PLC v. Kapur, 1989 I.R.L.R. 57, 61 (E.A.T.) (purpose to eliminate discrimination on the basis of race). In James v. Eastleigh Borough Council, [1990] 2 All E.R. 607, 617, 622 (H.L.), Lord Lowry and Lord Goff agree regarding the purpose or policy of the Sex Discrimination Act of 1975, that is, active promotion of the equal treatment of men and women, but they disagree regarding the implications of recognizing this purpose. Lord Lowry emphasizes that a court must still follow the words of the statute. Id. at 622 .

117. In Pepper v. Hart, [1993] 1 All E.R. 42, 49-51 (H.L.), the opinions of Lord Griffiths and Lord Browne-Wilkinson accept a "purposive" rather than a "literal" approach to statutory interpretation. This reliance on purpose undergirds an exception to the rule that courts may not look to Hansard.

118. Lord Lowry's opinion in James v. Eastleigh Borough Council, [1990] 2 All E.R. $607,622-25$ (H.L.) touches on this conflict by emphasizing that purpose must play in harmony with the words chosen rather than in opposition to them.

119. In Mandla v. Dowell Lee, [1983] 1 All E.R. 1062, 1069 (H.L.), Lord Fraser rejects a dictionary definition of "ethnic" because it is inconsistent with what Parliament must have intended. But he constructs an interpretation of the term which he seems to support in part as its most common meaning. He does reject, however, a literal meaning of "can comply" because it would deprive ethnic groups of much of the protection Parliament intended to give them. In Hampson v. Department of Educ. and Science, [1990] 2 All E.R. 513 (H.L.), the House of Lords relies in part on policy to reach a narrow construction of an immunity in the Race Relations Act of 1975. But the broad construction need not be viewed as the more ordinary or common meaning of the provision. In the Court of Appeal, Balcombe believed that the wider construction was the more natural meaning of the words but adopted a more narrow construction based on the context of the language and policies to be served by the immunity. See infra notes 181-84. 
The judicial practice of attaching meaning to words without reference to any source, the similar practice regarding findings of purpose, and the ability of judges to select interpretations of language suggest that reliance on the words of the statute does not reduce, but rather increases, the discretion of judges. In fact, judges' ability to defend their interpretations as preexisting in the language of the statute allows them to choose statutory meaning while avoiding discussion of the social policies the statute seeks to implement.

It is not surprising that the discretion inherent in plain-meaning interpretation can challenge the goals and purposes of social legislation, such as race and sex discrimination statutes. Plain meaning, of necessity, draws on common meanings imposed by culture and society. These common meanings, however, can hide other meanings from view and reinforce cultural systems that encourage or permit discrimination. It is instructive that, in Mandla v. Dowell Lee, Lord Fraser's reference to a definition of "ethnic"-a definition "consistent with the ordinary experience of those who read newspapers at the present day"120_echoes the initial conceptions of the "reasonable man" in tort law: the man "who takes the magazines at home and in the evening pushes the lawn mower in his shirt sleeves." 121 Leslie Bender argues that these images confine the meaning of words and reinforce existing perceptions and stereotypes. ${ }^{122}$ Denied parliamentary statements of purpose, judges are left with culturally directed plain meaning that can be strikingly at odds with the social reforms underlying a statute. For instance, although it included Sikhs in the definition of "ethnic," the House of Lords constructed a test for the term that seems inconsistent with a broader approach to interpretation advocated by Parliament. ${ }^{123}$ The test excludes groups Parliament likely intended to include. ${ }^{124}$

This culturally constructed plain meaning takes on legal significance only when refracted through the prism of the judge's personal experience. In England, the judges exercising the discretion inherent in plain-meaning interpretation are a remarkably homogeneous group and an extremely small portion of English society. "[English judges] are predominantly wealthy white males of late middle age, a very large percentage of whom were

120. Mandla v. Dowell Lee, [1983] 1 All E.R. 1062, 1066 (H.L.).

121. Leslie Bender, A Lawyer's Primer on Feminist Theory and Tort Law, 38 J. LEGAL ED. 3, 22 (1988) (footnote omitted).

122. Id. at 22-25.

123. See discussion infra notes 210-11.

124. See supra note 94 . Likewise, refusals to see discrimination against pregnant women as gender-based are "vindications of stereotyped views[,]" and similar stereotyping may be involved in the failure to recognize hostile environment cases of sexual harassment. Gerald P. McGinley, Judicial Approaches to Sex Discrimination in the United States and the United Kingdom-A Comparative Study, 49 MOD. L. REV. 413, 417-19, 426-27 (1986). 
educated at the same two universities. . . . [These judges] tend to know each other and have a strong common legal culture since their country and profession are relatively small." 125 Without questioning their integrity, it may be said that the background and experiences of judges cannot help but influence the ways in which they read and interpret the statutory language before them. Indeed, the issue is not primarily one of judicial integrity, for, even assuming that judges act with integrity and probity, literalism and plainmeaning interpretation cannot prevent judges from introducing political and social judgments into their interpretations. Such judgments are inherent in plain-meaning interpretation, and those judgments are likely to be antagonistic to the goals and purposes of much social legislation. The absence of legislative history removes an important constraint on judicial discretion.

The general observations about the character of judicial decisionmaking without legislative history suggest that much social legislation would not fare well in the world envisioned by the critics of the use of legislative history. Specific examples support these general observations.

The six groupings of opinions that follow further illustrate the weaknesses of plain-meaning interpretation. ${ }^{126}$ All six suggest that the resolution of many conflicting interpretations concerning important statutory policies is often arbitrary. The first grouping shows how the comparison required by the statute cannot be constructed simply by examining the language of the provision. The second grouping of opinions demonstrates that plain-meaning interpretation fails to account for the ways in which context can modify the meaning of terms. The third and fourth illustrate the dangers of relying on dictionary definitions and exemplify how plainmeaning interpretation can undermine the purposes and goals of a statute. The fifth grouping indicates that the interpretive techniques open to the courts in plain-meaning interpretation suffer from a lack of supporting

125. Jordan, supra note 66 , at 39 (citations omitted).

126. These groupings have been chosen for their illustrative value and because they address significant issues under the Race and Sex Discrimination Acts. Other groupings of opinions which interpret words and phrases in the statutes reflect many of the same problems of interpretation under the English rules regarding the use of legislative history. For opinions addressing "victimization," particularly the necessary relationship between the alleged retaliatory act and the race or sex discrimination statutes, see Aziz v. Trinity St. Taxis Ltd., [1988] 3 W.L.R. 79, 87 (E.A.T.); Subasinghe-Sharpe v. London Borough of Brent, E.A.T./583/89 (1992) (transcript); Cornelius v. University College of Swansea, 1987 I.R.L.R. 141, 142 (C.A.). For opinions addressing "in relation to death or retirement," see Finnegan v. Clowney Youth Training Program Ltd., [1990] 2 All E.R. 546, 548 (H.L.); Duke v. Reliance Systems Ltd., [1987] 2 All E.R. 858, 859 (C.A.); Roberts v. Cleveland Area Health Auth., 1979-I.R.L.R. 244, 246 (C.A.). For opinions addressing "a deliberate omission" or "act extending over a period," see Barclays Bank plc v. Kapur, [1991] 1 All E.R. 646, 649 (H.L.); Sougrin v. Haringey Health Auth., 1992 I.R.L.R. 416, 417 (C.A.). 
legislative history. The final grouping emphasizes that, absent the legislative history, no plain-meaning interpretation can rationally resolve the issue in dispute.

The first grouping of opinions addresses whether dismissal for pregnancy constitutes unlawful discrimination under the Sex Discrimination Act of 1975. In its opinion in Turley v. Allders Department Stores Ltd., ${ }^{127}$ the Employment Appeal Tribunal found that a dismissal on the grounds of pregnancy was not discrimination under the Act. It rested its decision on the indirect discrimination provision of the Act that required the comparison of a person of one sex with a similarly situated person of the other sex. ${ }^{128}$ Because no man could become pregnant, the Act's indirect discrimination provisions could not apply. Likewise, direct discrimination could not be found because not all women are or become pregnant; therefore, any resulting discrimination did not turn on gender.

Subsequently, in Hayes v. Malleable Man's Club and Inst., ${ }^{129}$ the E.A.T. limited the application of Turley. The E.A.T. found no difficulty "in visualising cases-for example, that of a sick male employee and a pregnant woman employee, where the circumstances, although they could never in strictness be called the same, could nevertheless be properly regarded as lacking any material difference. 130 In many circumstances, dismissal resting on pregnancy would be covered by the Act. The House of Lords resolved this conflict by permitting comparison between the treatment of a pregnant woman and that of a hypothetical ill man whose illness would confront the employer with circumstances not materially different than those regarding a pregnant woman. ${ }^{131}$

These opinions, in attempting to define a similarly situated person for purposes of comparison, expose the central issue in the prohibition against gender discrimination: what is to be compared with what? The construction of the appropriate comparison requires an understanding of the purpose of the statute; indeed, it requires a philosophy of gender equality and discrimination. But the language cannot provide this philosophy. This philosophy can be formed either with the aid of the legislative history or by the predilections and perspectives of judges alone.

The opinions in Mandla v. Dowell Lee ${ }^{132}$ and in Raval v. Department

127. 1980 I.R.L.R. 4, 5-6 (E.A.T.).

128. Id. at 5. The Employment Appeal Tribunal also noted that the Act did not expressly prohibit discrimination on the basis of pregnancy. Id.

129. 1985 I.R.L.R. 367 (E.A.T.).

130. Id. at 370 . Turley was distinguished as a decision on a narrow point, purely hypothetical, and too-lacking in "factual content to be applied by analogy to the circumstances of any other case." Id. at 369.

131. Webb v. E.M.O. Air Cargo (U.K.) Ltd., 1993 I.R.L.R. 27, 30 (H.L.).

132. [1983] 1 All E.R. 1062 (H.L.). 
of Health and Soc. Sec. ${ }^{133}$ illustrate a different problem. Both opinions address a requirement for establishing indirect discrimination: that the defendant imposes upon a member of a racial group a requirement or condition of such a character that a smaller proportion of that racial group "can comply" with the condition than can members of other groups. In Mandla, Lord Fraser rejected a literal interpretation of "can comply" on grounds that an emphasis on actual ability to comply would violate the intent of Parliament in prohibiting ethnic discrimination. ${ }^{134}$ Therefore, "can comply" included customs, beliefs, and practices that prevented a Sikh from following a requirement within his physical ability to perform-not wearing a turban. ${ }^{135}$

In Raval, an industrial tribunal, relying on Mandla, found that Asians had the same ability to comply with criteria regarding English competency as any other group having the same intelligence and ability. ${ }^{136}$ The E.A.T. disagreed, reasoning that "can comply" referred to the ability to produce evidence of previous satisfaction of the requirement and not to the ability to. acquire such proficiency in the future. ${ }^{137}$ The Tribunal's interpretation of "can comply" as "can comply in practice," although reasonable in the context, seems in tension with parliamentary policy that supported the definition in Mandla, ${ }^{138}$ a policy that stresses other aspects of the term beyond practical compliance.

These opinions disclose how context can modify the meaning of terms. Indeed, separation of the definition adopted in Mandla from its context illustrates that the meaning of a statutory term can never be completely fixed either by reference to a dictionary or by judicial adoption of a definition. Purpose and context continue to influence meaning.

This ambiguity of meaning reflects general aspects of language-"every word has a different character in different contexts." 139

133. 1985 I.R.L.R. 370 (E.A.T.).

134. [1983] 1 All E.R. at 1069. A literal definition would deprive members of groups defined by reference to ethnic origins "of much of the protection which Parliament evidently intended the 1976 Act to afford them" because "they 'can' comply with almost any requirement or condition if they are willing to give up their distinctive customs and cultural rules." Id.

135. Id. The opinion approved the meaning given to "can comply" by the Employment Appeal Tribunal in Price v. Civil Serv. Comm'n, [1978] 1 All E.R. 1228, 1230 (E.A.T.).

136. Raval v. Department of Health and Soc. Sec., 1985 I.R.L.R. 370, 374 (E.A.T.). Promotion in the Civil Service clerical grades required an " $O$ " level in an English language examination. Id.

137. Id.

138. 1d. The Employment Appeal Tribunal believed that the definition of "can comply" as "can comply in practice[,]" "if anything, [rules out] the broad approach favoured by the Industrial Tribunal in this case." ld.

139. LUDWIG WITTGENSTEIN, PHILOSOPHICAL INVESTIGATIONS 181 (G.E.M. Anscombe trans., 1958). 
The meaning of a word or of a sentence derives from its reference, its purpose. ${ }^{140}$ These general aspects of language pose special difficulties for plain-meaning interpretation, which seeks to fix a single "plain meaning" and simultaneously deny the most significant statements of purpose.

Other groupings of opinions emphasize the danger of relying on dictionary definitions of statutory terms. Persons claiming that they have been subjected to indirect discrimination prohibited by the Sex and Race Discrimination Acts must establish that they have been subjected to a "requirement or condition" that has a disproportionate impact on others of their gender or racial group. Opinions in Perera $v$. Civil Serv. Comm ' $n^{141}$ and in Meer v. London Borough of Tower Hamlets ${ }^{142}$ confronted criteria for appointment to a government position that were not absolute but which were weighed with others in the employment decision. ${ }^{143}$ Without expressly so stating, the Court of Appeal in Perera seemed to rely on the ordinary meanings of "requirement" and "condition" and held that, to fall under the Race Relations Act, criteria for appointment must be absolute; that is, an applicant who did not meet the criteria would not even be considered for employment. ${ }^{144}$ Therefore, even if one or more of the criteria for selection adversely affected the applicant, no claim of discrimination could be lodged. Employers, therefore, could include criteria difficult for women or minorities to meet without violating the Act.

One of the opinions in Meer stated that this definition of "requirement or condition" "may not be consistent with the object of the Act." ${ }_{145}$ The opinion, although noting extensive criticism of Perera by civil rights groups, acknowledged that "Perera [as precedent of the Court of Appeal] is binding on us." 146

140. Id. at $188 \mathrm{e}$.

141. 1983 I.R.L.R. 166 (C.A.).

142. 1988 I.R.L.R. 399 (C.A.).

143. In Perera, the applicant had applied for a civil service position, selection for which was based on four factors: experience in the United Kingdom, good command of the English language, British nationality or an intention to apply for it, and age. 1983 I.R.L.R. at 167. In Meer, the applicant applied for a position as a solicitor with local government, selection for which was based on ten factors: age, date of admission as solicitor, present post, current salary, local government experience, London government experience, Inner London government experience, senior management experience, length in present post, and Tower Hamlets experience. 1988 I.R.L.R. at 400.

144. 1983 I.R.L.R. at 169. The court suggested that a number of factors taken together might produce a requirement or condition "if the evidence had established that the combined lack of a number of those factors constituted an absolute bar to selection." Id.

145. 1988 I.R.L.R. at 403. In this instance, it seemed unlikely that any Indian solicitor would have any experience in the Tower Hamlets. Id. at 400 .

146. Id. at 403. Court of Appeal decisions of one panel are binding on other panels of the Court of Appeal. Duke v. Reliance Systems Ltd., 1987 I.R.L.R. 139, 140-41 (C.A.) (reaffirming the rule). In Meer, Balcombe, L.J., referred to an article that stated, "Perera was 
The dictionary definition of "requirement or condition" can render the statute ineffective in altering practices or procedures that perpetuate discrimination. A 1994 decision $^{147}$ illustrates the detrimental effects of the definition and the continuing viability of Perera. A black applicant for a position with a unit of local government was rejected in favor of a white person temporarily holding the job. One "desirable" criterion for appointment was service in the type of program in which the in-house candidate was employed. The agency had no black employees (it seems it had never had any black employees) able to acquire this experience. The Employment Appeal Tribunal, finding that Perera could not be distinguished on the ground that it involved multiple factors to be considered while this case included only one, concluded, "[w]e are aware there has been criticism in high quarters of the Perera decision. ... We [are] unable in the hierarchy of judicial precedent, to entertain an argument that a decision of the Court of Appeal is wrong." 148 The legislative history suggests a much broader meaning of the terms.

A similar dispute surrounded the interpretation of the term “justifiable." In both the Sex and Race Discrimination Acts, a defendant who has been found to have committed an act of indirect discrimination by imposing a requirement or condition having disparate impact may argue that the requirement was justifiable. The E.A.T., relying on the goals of the Race Relations Act, had interpreted "justifiable" to mean necessary for carrying on the defendant's business and to mean reasonably necessary in all the circumstances under the Sex Discrimination Act. ${ }^{149}$

In Ojutiku v. Manpower Services Comm'n, ${ }^{150}$ the Court of Appeal rejected these interpretations. Two opinions in this case did so by relying on the dictionary definitions of "justifiable:" "to adduce adequate grounds for" 151 and "advancing good grounds," 152 respectively. Therefore, a person who gives reasons "acceptable to right-thinking people as sound and tolerable reasons . . . has justified his conduct." 153 The broader interpretations of "justifiable" were an unneeded "gloss" because

one of the worst decisions ever under discrimination law and many hoped it would quietly disappear." 1988 I.R.L.R. at 403.

147. Meikle v. Nottingham City Council, E.A.T./249/92 (1994) (transcript).

148. Id.

149. Steel v. Union of Post Office Workers, 1977 I.R.L.R. 288, 290 (E.A.T.). One test for necessity was whether other nondiscretionary methods were not available to achieve the same result. Id. at 291.

150. 1982 I.R.L.R. 418 (C.A.).

151. Id. at 421 (opinion of Eveleigh, L.J.). "But if I have to give some explanation of my understanding of that word, I would turn to a dictionary definition ...." Id.

152. Id. at 422 (opinion of Kerr, L.J.). " '[A]dvancing good grounds' is one of the dictionary definitions of the verb 'to justify'." Id.

153. Id. at 421 . This is the position taken by Eveleigh, L.J. 
"justifiable" "is a perfectly easily understandable ordinary word . . that . . clearly applies a lower standard than the word 'necessary'." 154

In Hampson v. Department of Educ. and Science, the Court of Appeal found the meaning assigned to "justifiable" by the opinions in Ojutiku to be less than clear. ${ }^{155}$ The term "justifiable," as well as the definitions given for it, involve value judgments that cannot be separated from the circumstances of each case. ${ }^{156}$ "Justifiable" requires "an objective balance between the discriminatory effect of the condition and the reasonable needs of the party who applies the condition." 157 This approach rejects justification by mere convenience. ${ }^{158}$ Subsequently, the House of Lords indicated that "justifiable" requires an "objective balance" between the discriminatory effect of the "requirement or condition" and "the reasonable needs of the party who applies the condition." 159 The result of these attempts to give a plain meaning to the term "justifiable" was the creation of a normative balancing test.

The fifth grouping of opinions demonstrates the interplay between analysis of specific terms of the statute and articulations of purpose. The opinions marshal most of the interpretive techniques available without the use of legislative history. In one case, a local council had used a neutral term, "pensionable age," as the basis for providing free access to some local services even though the differences in pensionable age for men and women meant that men from ages sixty to sixty-five would continue to pay fees while women of the same age would not. Opinions of the Court of Appeal and the House of Lords in James v. Eastleigh Borough Council considered, under the Sex Discrimination Act, the meaning of the requirement for recovery that the complainant be treated less favorably "on the ground of [the complainant's] sex." 160 The opinions addressed whether this requirement was objective or subjective and whether it focused on causation

154. Id. at 422 . This is the position taken by Kerr, L.J.

155. 1989 I.R.L.R. 69, 75 (C.A.) (opinion of Balcombe, L.J.) ("With all due respect to these two learned lords justices, I derive little help from these judgments.").

156. That a value judgment is involved "is evident from the dictionary definition cited by Lord Justice Eveleigh." Id.

157. Id. The opinion believed that this meaning of "justifiable" was supported by Rainey v. Greater Glasgow Health Bd., 1987 I.R.L.R. 26, 30-31 (H.L.) (cited in 1989 I.R.L.R. 69, 75 (C.A.)).

158. Id. The Ojutiku opinion relied on the reasoning of the Employment Appeal Tribunal which emphasized that convenience alone would be insufficient justification. Id. (citing Steel v. Union of Post Office Workers, 1977 I.R.L.R. 288, 291 (E.A.T.)).

159. Webb v. E.M.O. Air Cargo (U.K.) Ltd., 1993 I.R.L.R. 27, 30 (H.L.) (quoting Hampson v. Department of Educ. and Science, 1989 I.R.L.R. 69. 75 (C.A.)). "This test must now be regarded as the appropriate one and as superseding that of Eveleigh $\mathrm{L}$ in Ojutiku." Id.

160. [1989] 3 W.L.R. 123, 127 (C.A.); [1990] 2 All E.R. 607, 607 (H.L.). 
or on state of mind. The Court of Appeal, concerned with what an objective reading of "on the ground of [the complainant's] sex" would mean for the structure of the Act, ${ }^{161}$ held that the term looked to whether "the defendant has [subjectively] treated the plaintiff less favourably because of his or her sex." 162 Crucial to this subjective test were the "reasons that I am seeking to give, not my intention or desire to administer the law correctly." 163

The opinions in the House of Lords illustrate the variety of interpretive approaches discussed earlier. Lord Lowry's dissenting opinion rejected a purely causative "but-for" test for the terms, that is, a test which asks whether the complainant would have received the same treatment from the defendant but for his or her sex. ${ }^{164}$ This rejection rested in good part on the phrases of the appropriate sentence in the statute. "These words ['on the ground of the complainant's sex, the defendant treats the complainant less favourably than he treats or would treat a person of the opposite sex'] . . . constitute an adverbial phrase modifying the transitive verb 'treats' in a clause of which the discriminator is the subject and the victim is the object." 165 Moreover, the dictionary definition of "ground" "invites consideration of the mental processes of the decision-maker." 166 The

161. James v. Eastleigh Borough Council, [1989] 3 W.L.R. 123, 128 (C.A.). The opinion stated that an interpretation focusing on whether there was a "substantial causative link between the defendant's treatment and the detriment suffered by the plaintiff as the result of [the plaintiff's] sex" would leave "no room for the operation" of the provision of the Act which concerned indirect discrimination. Id. at 129.

In every case in which a sexually neutral condition in fact operates differentially and detrimentally to one sex as opposed to the other, the imposition of such condition would be a substantial cause of detriment to the plaintiff by reason of his or her sex, i.e., it would fall within . . . [the] causation test and therefore constitute direct discrimination . . . .

Id.

162. Id. at 128. This position was supported in part by the Act's emphasis on the activities of the alleged discriminator and suggests that the courts should look "to the reason why the defendant treated the plaintiff less favourably." Id.

163. Id. at 129. This interpretation addresses the concern that imposition of an intent requirement would make proof of discrimination more difficult and invite evasion and manipulation.

164. James v. Eastleigh Borough Council, [1990] 2 All E.R. 607, 619 (H.L.) (opinion of Lord Lowry). Lord Goff articulated this as the question that would resolve most cases concerning direct discrimination. Id. at 617.

165. Id. at 619. The grammatical construction of the sentence directs that "the ground on which the alleged discriminator treats the victim less favourably is inescapably linked to the subject and the verb; it is the reason which has caused him to act." Id.

166. Id. at 620. Lord Lowry relies on the definition of "ground" in the Oxford English Dictionary (2d ed. 1989): "a circumstance on which an opinion, inference, argument, statement or claim is founded or which has given rise to an action, procedure or mental feeling; a reason, motive. Often with additional implication: A valid reason, justifying motive, or what is alleged as such." Id. 
subjective meaning of the term uses "ground" "in its natural meaning, whereas the causative construction suppresses the natural meaning."167 "[T] he causative ["but-for"] test is too wide and is grammatically unsound, because it necessarily disregards the fact that the less favourable treatment is meted out to the victim on the ground of the victim's sex." 168 The policy of the Act, to discourage discrimination and promote equality, is insufficient to support a meaning not carried by the words of the statute. ${ }^{169}$ As a result, " $[t]$ he phrase 'on the ground of his sex' does not . . . constitute an exception to the policy and therefore does not fall to be narrowly construed." 170 The determination, then, of whether the defendant discriminates against the complainant "on the ground of [the complainant's] sex" "involves a question of fact, the answer to which will depend on what is proved or admitted and on what may be inferred from the evidence." 171

In his opinion, with which a majority of the panel agreed, Lord Bridge relied on precedent, adopting an objective test based on causation. In a previous decision, the House of Lords concluded that the "intention or motive of the defendant to discriminate . . is not a necessary condition to liability" because a defendant might have no motive to discriminate but in fact do so. ${ }^{172}$

Lord Lowry disagreed with Lord Bridge and found the precedent less convincing because in that case, where the reason given for less-favorable treatment did rest on gender, the defendant would have lost under either construction of the language, "and no rival constructions of that provision were discussed." 173

Lord Goff, the architect of the causative and objective test, ${ }^{174}$ justified its application on the basis of the Act's policy of promoting equal treatment of men and women. ${ }^{175}$ Lord Goff recognized that the test might include

167. Id. at 622 . "The phrase 'on the ground of does not mean 'by reason of'; moreover, 'ground' must certainly not be confused with 'intention'." Id.

168. Id. at 623. Lord Lowry believed that the causative test not only dispensed with often irrelevant mental states, such as malice, prejudice, desire, and motive, but also "with an essential ingredient, namely the ground on which the discriminator acts." Id.

169. Id. at 622 . "But the Act pursues that policy by means of the words which Parliament has used." Id.

170. Id. Rather, the words are an essential ingredient of a claim for direct discrimination. Id.

171. Id. at 625 . Lord Lowry noted that merely because a defendant's action has a foreseeably discriminatory result does not necessarily indicate the grounds on which the defendant acted. Much depends on the circumstances. Id. at 624-25.

172. Id. at 612 (quoting Equal Opportunities Comm'n v. Birmingham City Council, [1989] 1 All E.R. 769, 774 (H.L.)).

173. James v. Eastleigh Borough Council, [1990] 2 All E.R. 607, 623 (H.L.).

174. Lord Goff wrote the opinion in Equal Opportunities Comm'n v. Birmingham City Council, [1989] 1 All E.R. 769, 771-76, on which Lord Bridge relied.

175. James, [1990] 2 All E.R. at 617. Consistent with this policy, "on the ground of [the 
intention, that is, an intention to perform "the relevant act of less favourable treatment"; yet he believed that in the majority of cases, it was unnecessary to consider either intention or the motive underlying it. ${ }^{176}$

These various opinions illustrate the range of interpretive approaches open to courts in the absence of legislative history. In particular, these opinions show that interpretations relying on purpose or policy suffer from the lack of supporting legislative history that might give clearer direction to the statutory analysis.

The final grouping of opinions emphasizes that any plain-meaning interpretation fails to rationally resolve the issue in dispute. These opinions address a technical issue, namely, how to interpret the exception which states that the prohibitions in the Race Relations Act against indirect discrimination, among others, "shall [not] render unlawful any act of discrimination done . . . in pursuance of any instrument made under any enactment by a Minister of the Crown." 177

When the Secretary of State for Education, under the Education Act of 1980 , issued regulations establishing the equivalency of foreign training for purposes of certifying teachers, these regulations had a disparate impact on the ability of some foreign-trained teachers to become certified. ${ }^{178}$ The Court of Appeal in Hampson, considering whether the exception just quoted gave the Secretary of State immunity, in one opinion applied the terms of the statute, finding that they fit the circumstances of the case. ${ }^{179}$ Moreover, the

plaintiff's] sex" not only refers to the reason for the defendant's actions but also embraces "cases in which a gender-based criterion is the basis on which the complainant has been selected for the relevant treatment." Id.

176. Id. at 618. The causative test made it unnecessary for industrial tribunals to struggle with the elusive concepts of intention and motive in the daily administration of the law, Id.

177. Race Relations Act, 1976, ch. 74, §41(1) (Eng.). As these opinions which interpret the Race Relations Act demonstrate, without the legislative history, no rational plain meaning can be said to exist. See discussion infra notes 214-19.

178. Hampson v. Department of Educ. and Science, 1989 I.R.L.R. 69, 72 (C.A.).

179. Id . at 73. One interpretation, the wider one, granted immunity when the minister was exercising any power or discretion under an enactment; another, the narrower one, granted immunity only for actions taken in the necessary performance of an express obligation contained in the instrument. Id. Parker, L.J., adopting neither position, stated:

It appears plain to me that when the Secretary of State made the Regulations he was acting in pursuance of an enactment with the meaning [of the section] notwithstanding that the Act conferred a wide discretion and that there were many options open to him as to the qualifications which he might require teachers to possess.

Id. at 79. Balcombe, L.J., who adopted the narrower interpretation, believed that although "both constructions [were] possible, . . the wide construction is the more natural meaning of the words used." Id. at 73. Yet he justified the narrow construction on the basis of the section's context. Id. Nourse, L.J., believed that the immunity applied based on "the facts of this case," and, "[l]ike Lord Justice Parker, [he] certainly regard[ed] it as being neither possible nor desirable to attempt the formulation of a universal test." Id. at 77. 
author of the opinion believed that Parliament would not have authorized an industrial tribunal to override the judgment of the Secretary, which was required to be exercised in an Act of Parliament. ${ }^{180}$

The Court of Appeal in Hampson, in another opinion, argued for a more narrow interpretation of the exception. ${ }^{181}$ The immunity applied only when the Secretary was implementing an obligation specifically imposed by a parliamentary enactment. The exception did not apply when the minister was exercising discretion given by an Act of Parliament. The author of this opinion relied, in part, on the conflict between a broader scope of the exception and specific provisions of the Race Relations Act, ${ }^{182}$ as well as the policy of reconciling the Race and Sex Discrimination Acts. ${ }^{183}$ Finally, the immunity applied when Parliament established the discriminatory condition or requirement, but it did not apply when the choice rested with a minister who should be required to show that any discriminatory condition was justifiable. ${ }^{184}$

The two opinions also disagreed about the significance of differences between the immunity language of the Sex Discrimination Act, which was more narrow, and that of the Race Relations Act, which was relatively broad. One opinion that was unable to summon any rational reason for the difference fell back upon the general policy that the Acts were to follow the same structure. ${ }^{185}$ The other opinion, also presenting no reason for the

\section{Id. at 79 .}

It is also at first sight equally difficult to suppose that it was within the intention of Parliament that, having committed to the Secretary of State the power and duty to decide upon the requirements which must be possessed by teachers, Parliament should have intended that his decisions should be subject, in effect, to being overruled by an Industrial Tribunal.

Id. This intention was made more difficult to find because of the extensive responsibility given to the minister in enforcing the Education Act. Id.

181. Id. at $72-74$.

182. ld. at 74. The comparable immunity section of the Sex Discrimination Act of 1975 was more narrow in its scope. Id.

183. The opinion relied on the White Paper on Racial Discrimination and the stated intention of the government "to harmonise the powers and procedures for dealing with sex and race discrimination so as to secure genuine equality of opportunity in both fields . . . . Except for good reason, the two statutes and the procedures for their administration and enforcement will be framed in similar terms." See Home OfFice, Racial Discrimination, Cmnd. 6234, at 48, 50 (cited in Hampson v. Department of Educ. and Science, 1989 I.R.I.R. 69, 74 (C.A.)).

184. Hampson v. Department of Educ. and Science, 1989 I.R.L.R. 69, 74 (C.A.). "If what is done is not necessary to comply with a statutory requirement, then there can be no valid reason why it should not have to be justified before an Industrial Tribunal." $I d$.

185. Id. "I cannot think of any good reason for [the markedly different wording of the immunity sections of the Race and Sex Discrimination Acts]. Why should statutory authority confer a wider licence to discriminate on the grounds of race than on the grounds of sex?" Id. (opinion of Balcombe, L.J.). 
difference in the language, assumed that Parliament intended the exception provisions in the two Acts to vary. ${ }^{186}$

Likewise, the House of Lords believed that the language carried two possible constructions. ${ }^{187}$ Although the language "in pursuance of" was more limited in the context of Section 41 than were terms used to describe other immunities in the section and suggested broad construction of the immunity, the narrow construction was necessary because a more expansive construction of the immunity was "irreconcilable with the purpose and meaning of the 1976 Act." ${ }^{188}$ The House of Lords also believed that little basis existed for a wide construction which rested on the interpretation of the immunity provisions of the Sex Discrimination Act. ${ }^{189}$ The narrow interpretation of the immunity placed before Parliament for debate any requirement arguably leading to racial discrimination and was, therefore, an interpretation to be preferred. ${ }^{190}$

These opinions leave the reader with the unhappy conclusion that no opinion marshals a compelling argument for any specific interpretation. What appears, however, to be an unresolvable conundrum under plainmeaning interpretation seems more tractable in light of the legislative history. ${ }^{191}$

These six groupings of opinions reinforce the conclusions drawn from a more general analysis of the opinions; and along with those conclusions, they permit a judgment regarding the impact of the rejection of legislative history on judicial decision-making. These groupings emphasize that reliance on the words alone cannot only expand rather than limit judicial discretion but also obscure, even to judges, the choices that have been made.

186. Id. at 79. "The difference in wording between $\S 51$ of the 1975 Act to that used in $\S 41$ must also in my judgment be taken to have been deliberate and intended to produce a different result." Id. (opinion of Parker, L.J.).

187. Hampson v. Department of Educ. and Science, [1990] 2 All E.R. 513, 518 (H.L.) (opinion of Lord Lowry).

188. Id. "In view of the wide sweep of these provisions, the exceptions ought therefore, I suggest, to be narrowly rather than widely construed where the language is susceptible of more than one meaning." Id.

189. The difference in the two immunity sections negated the general statement of the White Paper that the Race and Sex Discrimination Acts were to be harmonized.

But these conclusions [that no argument of value for a narrow interpretation can be founded on the immunity provision of the Race Relations Act] do not support the respondent's argument for a wide construction of the words "in pursuance of ${ }^{m}$, particularly when one takes into account the wider field of exceptions created by $\S 41$ which, if the respondent's argument were accepted, would greatly enlarge the gap between $\$ \S 51$ and 41 . Id. at 520 .

190. Id. at 521 . "There is a sound argument, based on public policy, for drawing the line in this way. I refer to the need and the opportunity for parliamentary scrutiny." Id.

191. See discussion infra notes 214-19. 
Without any support for conclusions regarding purpose in the legislative history, many citations to purpose can represent either general propositions of little controversy, the value of which is therefore often limited, or statements of judicial preference masquerading as the intended meaning Parliament assigned to the words it chose. Even when purpose seems central, good-faith efforts to implement parliamentary purpose are handicapped by the lack of legislative materials.

Precedent magnifies the weaknesses of plain-meaning interpretation by fixing the meanings of the statutory provisions. Many decisions resolve interpretive problems by reference to previous interpretations. ${ }^{192}$ Precedent can prevent reconsideration of interpretations about which the court harbors considerable doubt. ${ }^{193}$ It is ironic that this reliance on precedent turns analysis toward the interpretation of the language used by judges in previously establishing the meaning of the statutory terms. In interpreting their own precedent regarding the race and sex discrimination legislation, the courts reject an interpretive approach, that relies on the specific words chosen, but prefer one that emphasizes broader readings of policy and purpose. ${ }^{194}$ Legislative history would give Parliament an ability to explain decisions underlying the statutory language in a way analogous to that by which a judge explains the holding of a case.

Precedent also may significantly limit the application of legislative history to the race and sex discrimination statutes under the recently created exceptions to the Hansard rule. Even if reference to legislative history might be permitted under the 1993 rule changes regarding the use of legislative history, examination of that history is foreclosed by precedent that interprets

192. It is not surprising that, as more and more precedent accumulates, many cases are resolved based on an interpretation of the precedent without analysis of the statutory terms. More recent cases illustrate this tendency. E.g., Meikle v. Nottingham City Council, E.A.T./249/92 (1994) (transcript); Wadman v. Carpenter Farrer Partnership, (1993) I.R.L.R. 374, 376-77 (E.A.T.); O'Neill v. Borough Council of Wellingborough, E.A.T./214/91 (1993); Select Appointments p.I.c. v. Vandenberghe, E.A.T./587/91 (1992) (transcript).

193. See supra text accompanying notes 141-48.

194. In Dawkins v. Department of the Env't, sub nom. Crown Suppliers PSA, 1993 I.R.L.R. 284, 287 (C.A.), the plaintiff had argued that the opinions of Lord Templeman and Lord Fraser in Mandla v. Dowell Lee, 1983 I.R.L.R. 209, 211, 214 (H.L.), did not clearly establish the meaning of the term "ethnic." In Dawkins the court replied:

[I]t seems to me that in making these criticisms [the counsel for plaintiff] falls into the error of equating the language used in speeches or judgments with that of a statute. In giving reasons for a decision a judge seeks to explain the basis on which he has reached his conclusion. The speech or judgment has to be read as a whole. It is very often possible to find one passage in a judgment which, because different language is used, gives a slightly different impression or has a slightly different nuance when compared with another passage.

1993 I.R.L.R. at 288. 
the statutory language. ${ }^{195}$

Reliance on precedent without reference to legislative history can create questionable, if not erroneous and almost perverse, interpretations. The House of Lords in Dockers' Labour Club v. Race Relations Bd. ${ }^{196}$ narrowly interpreted the terms "section of the public" in Section 2(I) of the 1968 Race Relations Act to exclude private clubs from coverage of the Act. The legislative history of the 1976 Race Relations Act, however, evidences parliamentary concern with the Dockers' Labour Club decision. ${ }^{197}$ The adoption of Section 25 of the 1976 Act was a repudiation of the rationale of

195. Id. at 287-88.

We gave careful consideration to the submission that this was a case where it would be appropriate to refer to the statement of the Home Secretary during the passage of the Race Relations Bill in 1965. It may be that we would have been persuaded that that was a suitable course to take if guidance as to the meaning of the words "ethnic origins" had not been given in the House of Lords in Mandla.

Id. This position reflects similar views in the United States with respect to the importance of precedent in statutory interpretation, such as the one expressed by Edward Levi that once the terms in a statute are defined by the court, precedent should prevent reconsideration of that definition. See generally EDWARD LEVI, AN INTRODUCTION TO LEGAL REASONING (1949); William N. Eskridge, Overruling Statutory Precedent, 76 GEO. L. J. 1361 (1988).

196. [1974] 3 All E.R. 592, 594-96 (H.L.). The decision excluded private clubs from the coverage of the 1968 Act on the ground that a private club did not provide services or facilities to a segment of the public. Id.

197. After extensive debate in committee, in the House of Lords, and in the House of Commons, Parliament adopted Section 25 of the 1976 Act, which extended antidiscrimination provisions to clubs of a certain size. During this debate, persons speaking for the government were critical of the Dockers' Labour Club case and emphasized that the coverage of private clubs should not rest on the distinction between public and private functions but on the importance of these clubs in the social fabric of life. To this extent, the debate rejected the holding in Dockers' Labour Club as well as the rationale for what services and facilities would or would not be covered by the Act. See generally PARL. Deb., H.C., OfFICIAL REPORT, STANDING COMM. A, 333-48 (May 18, 1976); id. at 353-95 (May 20, 1976); 374 PARL. DEB., H.L. (5th ser.) 538-63 (Sept. 29, 1976); 905 PARL. Deb., H.C. (5th ser.) 1554-57 (Mar. 4, 1976); 918 PARL. DEB., H.C. (5th ser.) 567-600 (Oct. 27, 1976). On several occasions, ministers rejected the rationale of the case and pointed to an application of the Act to all clubs based on the size of the club. For example:

As a matter of policy, the Government now regard the effects of this test [adopted in the Dockers' Labour Club case] as unacceptable, as we pointed out in the White Paper. ... Having reached the conclusion that the dividing line which had been drawn [in that case] between clubs in the public sphere and those in the private sphere was unacceptable, we were faced with the problem of devising a more acceptable one. . . In other words, we have adopted a criterion of size.

918 PARL. DEB., H.C. (5th ser.) 569 (Oct. 27, 1976) (ministerial statement); 905 PARL. DeB., H.C. (5th ser.) 1554, 1556 (Feb. 17, 1976) (ministerial statement); 374 PARL. DEB., H.L. (5th ser.) 558-59 (Sept. 29, 1976) (similar statement citing White Paper) (ministerial statement). 
the decision. ${ }^{198}$ Section 25 extended antidiscrimination provisions to private clubs of a certain size on the basis of the importance they played in the social fabric of the community. One of the evils of exclusion on the basis of race from these private clubs was the public humiliation suffered by members of racial minorities. ${ }^{199}$

Subsequently, the Court of Appeal relied heavily upon the House of Lords opinions in Dockers' Labour Club in narrowly construing Section 20(1) of the 1976 Act. In Hector v. Smethwick Labour Club, ${ }^{200}$ a group of rugby players sought to collect for charity in a private club. White members of the group were told to seek the permission of the manager, but the black member of the group was told that he could not collect within the club even if the manager agreed that white members of the group could. The Court of Appeal, in interpreting the phrase in Section 20(1) which applied the prohibitions of the Act to "a person concerned with the provision" of the relevant facility or service to the public, narrowly required that there be a continuing interest in providing the facility to a segment of the public. Therefore, even if the white members of the group could be viewed as having been given access to a facility, the exclusion of the black member was not covered by the Act because there was not a continuing undertaking to permit the public to solicit for charity in the club.

The court looked to the ordinary meaning of "concerned with" but quoted extensively from the opinions in Dockers' Labour Club to the effect that, although private clubs were not covered, aspects of their services which were open to the public were covered. The opinions in the Court of Appeal emphasized the importance of discriminators holding themselves out as providing goods, services, or facilities to the public.

At the least, the legislative history demonstrates that a broader reading of Section 20(1), permitted by the language, was preferable if not required. ${ }^{201}$ The absence of legislative history allowed reliance on precedent

198. See sources cited supra note 197.

199. Parl. Deb., H.C., Official Report, Standing ComM. A, 394 (May 20, 1976) (ministerial statement). One reason for covering private clubs under the 1976 Act was to ensure that members of ethnic minorities would not suffer the public humiliation of being turned away from private clubs. "We have all at some time suffered humiliation in our private lives, but no humiliation do we feel so keenly as public humiliation. That, if the pernicious habit of exclusion on racial grounds is not cured in clubs, is precisely what we risk." Id.

200. Hector v. Smethwick Labour Club, 1988 App. Cas. 467-68 (transcript).

201. Although the language of Section 25 only protects applicants, members, and associates from discrimination, an interpretation resting on the language of $20(1)$, which the Court of Appeal found to be not significantly different from the 1968 Act, would have to consider the purpose and goal of the Act in interpreting the terms "concerned with." The rationale of the Dockers' Labour Club case on which the court relied in narrowly construing the terms was undercut by the legislative history. In addition, the legislative history suggests that the type of evil which Section 25 addressed was precisely at issue in the court's 
which was clearly rejected in the legislative history and which led the court to accept conduct that parliamentary deliberations identified as a principal evil to be redressed by the 1976 Act.

In summary, an analysis of judicial opinions interpreting the Race and Sex Discrimination Acts shows that the rules regarding the use of legislative history have significantly influenced judicial interpretation of the race and sex discrimination statutes. As examples of comprehensive social legislation, these statutes have not fared well in a world of judicial interpretation without legislative history.

\section{LEGISLATIVE HISTORY OF THE SEX AND RACE DISCRIMINATION STATUTES}

The legislative history of these two statutes, examined in this section, consists of pre-parliamentary materials-specifically, the relevant government White Papers-and parliamentary materials, including the deliberations of the appropriate Standing Committees of the House of Commons and the debates in the House of Commons and in the House of Lords. With the exception of a rare reference to the White Papers, ${ }^{202}$ the judicial opinions discussed above do not refer to any of this material. The pre-parliamentary and parliamentary materials permit an examination of the influence of plain-meaning interpretation on the character of judicial decisions and on the legislative process.

\section{A. The Influence of Legislative History on Judicial Opinions}

Judicial opinions interpreting the two statutes address a number of issues, including those discussed above. Examination of the legislative history identifies a number of judicial decisions that are inconsistent with clear and authoritative legislative history. Also, the legislative history raises doubts about other judicial opinions that are sufficient to require additional justification for them. Finally, the legislative history is helpful in confirming correct but troublesome interpretations.

Parliamentary consideration of the Race Relations Act of 1976 referred to instances under the 1968 Race Discrimination Act in which either the Court of Appeal or the House of Lords gave the words of the statute a meaning clearly in conflict with the meaning assigned to it by government ministers responsible for moving the legislation through Parliament. ${ }^{203}$ These

interpretation of 20(1). See sources cited supra note 197.

202. See supra note 72.

203. In one instance, regarding the coverage of private clubs under the Race Relations Act of 1968, the Court of Appeal in Dockers' Labour Club had interpreted the Act contrary to what the government minister in charge of the bill had told the House of Lords that it meant. 
instances stirred, it seemed, both popular and parliamentary discontent. ${ }^{204}$ Some members of Parliament expressed concern about these deviations from parliamentary understanding of the meaning of terms but were assured by the Lord Chancellor that they represented "isolated examples" to be responded to by better drafting. The Lord Chancellor offered both a judgment and a challenge "that the drafting of this Bill, at any rate, whatever view he may take of its merits, is in an admirable condition?"20s

Unfortunately, the judicial opinions previously discussed present a somewhat different assessment of whether attention to drafting can avoid erroneous or limiting interpretations of the Race and Sex Discrimination Acts. Also, the legislative history demonstrates that several opinions at different levels in the judicial system reach interpretations of statutory terms clearly in conflict with the meaning assigned to the terms by government ministers responsible for moving the bill through Parliament.

Recall that the Court of Appeal reached the conclusion that Sikhs were not covered by the provisions of the Race Relations Act. ${ }^{206}$ A variety of specific references throughout the legislative history, however, show that Parliament intended Sikhs to be covered by the Act. ${ }^{207}$ In this instance, the

"The right way of looking at it is that the courts [if the Court of Appeal decision had stood] would have interpreted an Act of Parliament contrary to what Parliament had been assured it meant and was intended to do." 374 PARL. DEB., H.L. (5th ser:) 549 (Sept. 29, 1976). This concern generated the suggestion that a minister's statement as to the meaning of a term "should be written into the measure itself." Id. at 551. Criticism of Dockers' Labour Club and another decision on a similar issue was also expressed in the House of Commons. 905 PARL. DeB., H.C. (Sth ser.) 1554 (Mar. 4, 1976); id. at 1904 (July 8, 1976).

In the other instance, the House of Lords, in London Borough Council of Ealing v. Race Relations Bd., [1972] 1 All E.R. 105, 107-09 (H.L.), had interpreted the term "national origins" narrowly to include race but not nationality or citizenship. See HOME OFFICE, RACIAL DisCRIMINATION, 1975. Cmnd. 6324, at 56. At least some members of the House of Lords believed that Ealing confirmed the intention of the 1968 Act. 374 PARL. DEB., H.L. (5th ser.) 58 (Sept. 27, 1976).

204. For example, a former member of the appellate committee who was involved in the case interpreting the coverage of private clubs under the Race Relations Act of 1968 referred to the considerable criticism of the decision. 374 PARL. DEB., H.L. (5th ser.) 550 (Sept. 29, 1976).

205. Id. at 554-55.

206. Mandla v. Dowell Lee, 1983 I.R.L.R. 17, 20 (C.A.).

207. The White Paper, in discussing indirect discrimination, states that this prohibition would also apply to "clothing wom by employees (e.g., preventing the wearing of turbans or saris)." Home Office, RaCial DisCrimination, 1975, Cmnd. 6234, at 55; 918 PARL. Deb., H.C. (5th ser.) 492 (Oct. 27, 1976) (Minister of State for the Home Office used a Sikh wearing a turban as the example of how a practice violating the Act must be shown to be justifiable.); $i d$. (Minister of State for the Home Office, in giving practical examples of the basic evil of one person treating another less favorably because of some characteristic of the other person, included "Sikh."). Comments of other members of Parliament, including opponents of the legislation, support these ministerial statements and illustrate the assumption that the Act would cover Sikhs. E.g., PARL. Deb., H.C., Official Report, Standing 
House of Lords held that Sikhs were included in the protections granted by the Act. ${ }^{208}$ Likewise, the legislative history easily resolves the dispute as to whether gypsies are an ethnic group and intended to be protected by the Act. ${ }^{209}$

The Court of Appeal relied heavily upon dictionaries to define the specific term "ethnic," and the opinions in the House of Lords began the analysis with dictionaries. ${ }^{210}$ This approach not only allowed a definition of "ethnic" at odds with parliamentary understanding; it also ignored an approach to the interpretation of the term which was inconsistent with that of the Court of Appeal and unavailable to the House of Lords. When asked what the term "ethnic" added to attacking the evil at which the statute was directed, the government minister responded that it was difficult to give a precise and clear definition of ethnic origins. "The point is that the overall formula, 'colour, race, nationality, or ethnic or national origins,' encapsulates a wide variety of ideas-sufficiently wide to cover all the various manifestations of racial discrimination." 211 The legislative history thus espoused a meaning of the terms inconsistent with the attempt to define precisely each term. Consulting the legislative history not only could have prevented this interpretation by the Court of Appeal but also could have suggested a broader meaning to all these terms consistent with the policy of the Act to attack racial discrimination in all of its guises. The test developed by the House of Lords has been used by other courts to exclude groups which are likely included under the interpretive approach suggested by

COMm. A, 37 (Apr. 27, 1976) (speaker denigrating the effect of the Act, " [t] may be that a few sikhs will be able to wear turbans at work, but that will not fundamentally change the employment situation of coloured workers."); 374 PARL. DEB., H.L. (5th ser.) 45 (Sept. 27, 1976) (speaker noting that any change in practices in construction industry which now permits Sikhs to wear turbans would constitute discrimination).

One commentary criticized the courts' failure to refer to legislative history in deciding whether the 1976 Act covered Sikhs. Current Developments, Turban or not Turban-That is the Question (Mandla v. Dowell Lee), 1 THE LIVERPOOL LAW REVIEW 75, 86 (1983). "If the courts were permitted to investigate Hansard, they would have discovered that Sikhs were meant to be covered ... thereby saving all parties the expense of appeals . ... Therefore, use of Hansard will reduce problems of interpretation and reduce the number of appeals." Id. (footnote omitted) (citing other and additional legislative history).

208. Mandla v. Dowell Lee, 1983 I.R.L.R. 209, 213-14 (H.L.).

209. Commission for Racial Equal. v. Dutton, 1989 I.R.L.R. 8, 12 (C.A.) (disagreeing with E.A.T. decision that gypsies were not an ethnic group). PARL. DEB., H.C., OfFICIAL REPORT, STANDING COMM. A, 107 (May 4, 1976) (referring with approval to report of the Race Relations Board detailing how gypsies should be regarded as within the terms of the 1968 Race Relations Act) (ministerial statement).

210. See supra text accompanying notes 84-94.

211. 374 PARL. DEB., H.L. (5th ser.) 74 (Sept. 27, 1976). "To understand the formula, it may be helpful to consider the nature of the evils that this legislation is designed to tackle. It is easier to identify these practical examples than it is to define them, which . . . is what Clause 1 of the Bill is designed to do." Id. at 73. 
Parliament. ${ }^{212}$ It is ironic that Parliament's attempt to address broadly the manifestations of discrimination may have been in part a response to narrow judicial interpretation of the term "national origin" in the 1968 Race Discrimination Act. ${ }^{213}$

Other examples of the conflicts between the meaning assigned to a term by an opinion and the statements of government ministers may be less dramatic but are equally clear. As discussed above, judicial opinions suggested widely varying interpretations of the scope of immunity for acts done "in pursuance of any instrument made under any enactment by a Minister of the Crown." In one opinion was a broad interpretation of the immunity that covered all actions taken by government bodies under an enactment, and in another was a more narrow interpretation that limited the immunity when the government official exercises discretion in formulating the regulations. ${ }^{214}$ The legislative history suggests that Parliament adopted neither a narrow interpretation nor a wide one that would have given immunity to any government body exercising authority under a statute. ${ }^{215}$ As

212. Applying the factors articulated in Mandla, the Court of Appeal held that Rastafarians are not an ethnic group. Dawkins v. Department of the Env't, 1993 I.R.L.R. 284,288 (C.A.) (discussing opposing view but concluding that Rastafarians were not an ethnic group) (In this case the defendant admitted that the appellant was refused employment because he was a Rastafarian.).

213. See supra notes $196-202$ and accompanying text.

214. See supra text accompanying notes 177-91.

215. The decision of the House of Lords in Hampson relied on Balcombe's dissent in the Court of Appeal. In that dissent, a central basis for his narrow interpretation of $41(1)$ (b) was:

If an enactment, Order in Council or statutory instrument imposes requirements compliance with which may lead to racial discrimination, those requirements can be debated in Parliament and their justification considered there. Similarly, if a minister of the Crown imposes a condition or requirement compliance with which could lead to racial discrimination (see $\S 41(1)(c)$ of the 1976 Act) he can be made answerable in Parliament for his action. If what is done is not necessary to comply with a statutory requirement, then there can be no valid reason why it should not have to be justified before an industrial tribunal.

Hampson v. Department of Educ. and Science, [1990] 2 All E.R. 513, 521 (H.L.) ((citing Hampson v. Department of Educ. and Science, [1990] 2 All E.R. 25, 32 (C.A.)) (quoting Balcombe dissent)). Balcombe's argument assumes that $41(1)(c)$ encompasses acts made necessary by an enactment for which the minister would be answerable to Parliament and contrasts this with $41(1)$ (b) where the minister who exercises discretion would be answerable to an industrial tribunal.

The legislative history shows that Parliament believed that $41(1)(c)$ was a limited provision which was meant to ensure that immigration officers, among others, would be covered by the immunity. Work permit schemes were exercised through immigration rules and instruction, "and not all of these are the sort of instruction designated as instruments under Subsection (1)(b)." 374 PARL. DEB., H.L. (5th ser.) 762 (Oct. 1, 1976) (comments of Minister of State for the Home Office). Section 41(1)(c) addressed the problem of whether courts might apply the Act to certain officials although such officials were not intended to be 
to the narrow interpretation, the minister responsible for moving the Act through Parliament specifically declined to validate a suggestion that the exception be limited to ministerial actions that are subject to the approval of Parliament or to examination by an industrial tribunal. ${ }^{216}$ As the wide interpretation, the legislative history describes ultra vires in terms of action under a statute that contemplates discrimination in a way that precludes the wide construction. ${ }^{217}$ Moreover, the legislative history suggests a reason for the difference between the immunity provisions of the Race and Sex Discrimination Acts ${ }^{218}$ and raises a point for analysis not addressed by the courts. ${ }^{219}$

It is ironic that this language sought to clarify rather than to confuse the meaning of the immunity. Concerned with possible judicial misinterpretation, ${ }^{230}$ Parliament added the language at issue. In this instance,

covered. Id; see also PARL. DEB., H.C., OfFICIAL REPORT, STANDing COMM. A, 478 (May 27. 1976) (comments of Minister of State for the Home Office) (noting the nature of (1)(c)). Section $41(1)$ (c) was to insure that all officers were covered by the immunity provided in $41(1)$ (a) and (b). The Subsection 41 (1) as a whole was seeking to protect "discrimination which is required by or is in consequence of an Act of Parliament." 374 PARL. DEB., H.L. (5th ser.) 762 (Oct. 1. 1976). Therefore, principles applicable to $41(1)$ (c) would also apply to $41(1)(b)$. The discussion of (1)(c) suggests that any judicial examination of ministerial action under Subsection 41 (1) was to be limited and that 41 (1) covered exercises of ministerial discretion.

There is however a protection. If Ministers go outside their powers-the doctrine of ultra vires-[i.e., if they impose a condition which was irrelevant to the act of Parliament] or if they exercise their powers without regard to the rules of natural justice, they are answerable in the courts. They are answerable to Parliament for actions they take within their powers.

PARL. DEB., H.C., Official REPORT, StANDing COMM. A, 479 (May 27, 1976). In response. to a question as to whether the government had considered restricting the exception in 41 (1)(c) to orders which are subject to the approval of Parliament, the Minister of State for the Home Office replied that the Race Relations Commission could review whether the legislation was working and emphasized again the need for $41(1)$ (c) to insure that immunities attaching to actions in 41(1)(a) and (b) applied to instruments under the Immigration Act. Id. at 481 . Although the immunities would apply to orders not subject to parliamentary approval, the statute under which the minister acted "must contemplate discrimination, otherwise the Minister's action cannot be by virtue of that enactment." Id. The language which explains ultra vires does not impose a requirement that the statute must specifically direct the discrimination. It excludes from the immunity, however, discretionary actions that are performed pursuant to statutory authority which authorizes a variety of governmental bodies.

216. PARL. DEB., H.C., OFFICIAL REPORT, STANDING COMM. A, 481 (May 27, 1976).

217. Id. See discussion supra notes 168-69.

218. The legislative history suggests that the difference in the immunity provisions was influenced by the addition of $41(1)(c)$, that ensured that certain governmental officials would be protected. Id. at 478-79.

219. Section (I)(c) "is certainly narrower than Section 3(2) of the 1968 [Race Relations] Act which has attracted no criticism." Id. at 481 .

220. See supra note 218. 
without the legislative history, there is no plain-meaning interpretation.

Courts. had also disagreed regarding the meaning of the term "justifiable." Some courts held that "justifiable" was linked to necessity, others to convenience, and still others to a balance of the interests involved in the specific case. ${ }^{221}$ The legislative history demonstrates that Parliament unequivocally rejected an interpretation of "justifiable" linked to necessity. ${ }^{222}$ The legislative history shows that "justifiable" was intended to embody an objective test which involved a weighing of interests to be "decid[ed] as a matter of fact in each particular case."223 The legislative history thus permits a confident choice between varying interpretations of the language, a choice difficult to justify solely by definition of the specific term.

Courts also had considerable difficulty determining the appropriate measure of damages for direct discrimination. ${ }^{224}$ The legislative history establishes that Parliament assumed that damages would be interpreted broadly. The legislative history also expresses a concern with prior law about limited damages and emphasizes that the importance of recovery for injured feelings required a broad reading of the damage requirement. ${ }^{225}$ The

221. See supra text accompanying notes 149-59.

222. 362 PARL. DEB., H.L. (5th ser.) 1014-15 (July 14, 1975). In addressing whether first in-first out might be a "justifiable" means of dealing with a layoff, the Minister of State for the Home Office stated:

It seems to me that such a policy could well offer the fairest treatment to employees in this situation. But such a policy could be disallowed if we were to insert the word 'necessary' rather than keeping to 'justifiable.' I think that a requirement such as the Noble Baroness is putting forward could, quite unintentionally, cause a good deal of bitterness in an industrial situation where redundancies were forced upon an employer.

Id. at 1016. Commenting on an attempt to substitute "necessary" for "justifiable," a person speaking for the Government also stated:

First, perhaps I may say that the word 'necessary' is a more subjective test than the word 'justifiable', which I hope imports the concept of a just and fair test, whereas 'necessary' could be a rather more subjective test in that it might relate to the requirements of the person who was alleged to discriminate.

Parl. Deb., H.C., Official Report, Standing CoMm. B, $48-49$ (Apr. 22, 1975).

223. PARl. Deb., H.C., Official Report, Standing Comm. A, 39 (Apr. 27, 1976).

224. E.g., Coleman v. Skyrail Oceanic Ltd., 1981 I.R.L.R. 398, 401 (C.A.) (emphasizing the need to link injured feelings to knowledge of gender discrimination).

225. The White Paper on Sex Discrimination noted that the government was considering whether the damages previously available under the Race Relations Act of 1968 were adequate and whether general damages should be permitted. HOME OFFICE, EQUALITY FOR WOMEN, 1974, Cmnd. 5724, at 103. The White Paper on Racial Discrimination stated that under the 1968 Race Relations Act. damages had been limited to instances in which there were special damages or in which damage could be shown for lost opportunities. The White Paper stressed that damages for violation of the Race Relations Act should take into account injury to feelings. Home OfFice, RaCial Discrimination, 1975, Cmnd. 6234, at 42.

The Government take the view as a matter of principle that a person who has 
statements of the responsible minister in the legislative history, therefore, directly conflict with an otherwise available interpretation of the damage provision based solely on its language.

The large number of instances in which judicial interpretations have conflicted with the meaning given to a term by a responsible government minister suggests that the deviations from parliamentary intention which result from an inability to use the legislative history are more than "isolated examples" and that assumptions about the "admirable condition" of legislation were insufficient to prevent such interpretations. These instances also illustrate that interpretation without legislative history led to decisions at odds with the clear and authoritative statements of ministers contained in parliamentary deliberations.

In other instances, the legislative history less certainly establishes a conflict with some judicial interpretation but does cast doubt on that interpretation. The four examples which follow illustrate how the use of the legislative history might modify judicial interpretation or, at least, require some additional justification for the interpretation.

The House of Lords adopted an objective, causative test for the terms "on the ground of her sex," rejecting an interpretation resting on motive or intent. ${ }^{226}$ During consideration of an amendment that sought to delete the quoted language, the minister responsible for the legislation stated that the terms would not prevent an industrial tribunal from inferring an intent to discriminate from the circumstances. ${ }^{227}$ In the legislative history, this ministerial statement occurs with others which state that the section in which the terms are found was meant to address direct and "intentional" discrimination. ${ }^{228}$ These statements, as well as their context, cast doubt on

suffered less favourable treatment on racial grounds should be able to obtain damages for any injury to his feelings resulting from the discrimination. We also believe that he should be able to seek such damages, irrespective of whether he has suffered any other form of damage. As I have said, we thought it necessary to put this beyond doubt in the Sex Discrimination Act and we considered that it is necessary to do so in this Bill.

374 PARL: DEB., H.L. (5th ser.) 1027 (Oct. 4, 1976).

226. See supra text accompanying notes 160-76.

227. Parl. Deb., H.C., Official Report, Standing Comm. B, 12, 15-16 (Apr. 22, 1975) (ministerial statement).

If one compares the treatment of one person with that of another, the inference can easily be drawn by a tribunal or a court that there was an intention to discriminate. I do not think that simply using the words "on the ground of her sex" would allow people to drive a coach and horses through the Bill.

Id. at 17. The person proposing the amendment feared that use of the term would permit employers and others to fabricate other reasons-such as physical weakness, unreliability, or emotional instability-which reflected stereotypes of women. Id. at 11.

228. Prior to the proposed amendment some ministerial statements stressed that Section 
whether a "but-for" test for direct discrimination is consistent with this legislative history.

One court held that the prohibition against discrimination on the basis of marital status did not apply to the dismissal of an employee who announced that she was to be married. ${ }^{229}$ The court believed that the term "marital status" would not carry a meaning that permitted protection of a person who had not yet entered into that status. The legislative history does not specifically resolve this issue. Some general statements support the contention that single persons are not protected. ${ }^{230}$ Other statements, including one to the effect that the statute was intended to cover "any provision made in connection with marriage[,]"231 would permit a court to conclude that discrimination against a person to be married fell under that Act. This legislative history strengthens the ability of a court to interpret the Act so as to include attempts to circumvent its protections.

In a heavily criticized opinion, the Court of Appeal held that the terms "requirement" or "condition" covered only criteria that must be satisfied to be hired, not other criteria that were weighed in determining who would be hired. ${ }^{232}$ The legislative history would support a broader meaning of the terms. "Requirement" or "condition" was meant to respond to two aspects

1(a), in which the term was found, applied to "direct and intentional discrimination." Id. at 9 (ministerial statement and reference to an earlier statement of the same nature). In the debate regarding the Race Relations Act, the minister stated that he did not disagree with the statements of an opponent who equated direct discrimination with intention. PARL. DEB., H.C., OFFICIAL REPORT, STANDING COMM. A, 178 (May 6, 1976) ("Where I quarrel . . . in his frequent references to indirect discrimination is that he keeps referring to it as 'unintentional.' Indirect discrimination may be either intentional or unintentional."). The opinion of Lord Goff in the House of Lords highlighted the various meanings of "intention." See supra text accompanying notes 174-76. The discussion of the amendment, which would have deleted the words "on the ground of her sex," suggests that "intention" meant more than simply an intention to do the act that resulted in direct discrimination. For example, the minister referred to differences in damages which reflected the differences between intentional and accidental discrimination. PARL. DEB., H.C., OFFICIAL REPORT, STANDING COMM. B, 18 (Apr. 22, 1975). During the discussion, others referred to the discriminator's intention as "nefarious." Id. at 19-20.

229. Bick v. Royal West of Eng. Residential Sch. for the Deaf, 1976 I.R.L.R. 326, 327 (Industrial Tribunal). This issue, representative of those that generate few, if any, appellate decisions, is one in which legislative history could help inform the decision.

230. PARl. Deb., H.C., Official Report, Standing Comm. B, 54 (Apr. 22, 1975) (indirect discrimination deals with married and unmarried persons of the same sex); id. at 86 (Apr. 24, 1975) (not willing to subdivide that group of unmarried persons into groups such as widows, widowers, divorcees, bachelors, spinsters); id. at 89 (bill not covering single persons because "discrimination against single women is largely discrimination on grounds of sex and not because they are single.").

231. HoMe OfFICE, EQUALITY FOR WOMEN, 1974, Cmnd. 5724, at 42.

232. See supra text accompanying notes 141-48. 
of the term "unfavourable," a term deleted from the legislation. ${ }^{233}$ The phrase "to her detriment" replaced the term "unfavorable" and suggests a broad meaning not only for that phrase but also for "requirement or condition." 234 Moreover, examination of the legislative history pertaining to this language would have acquainted the court with statements regarding the broad scope and purpose of the law, ${ }^{235}$ statements much stronger and more specifically directed than judicial articulations of purpose derived from the preamble or from the long title. This acquaintance would have enabled a court, relying not on its own judgment but on that of Parliament, to construct a broader meaning of the terms.

Some of the prohibitions of the Race Relations Act of 1976 applied to "facilities" and "services," terms which some commentators believed the courts had unduly narrowed by interpretation. ${ }^{236}$ The legislative history suggests a broader meaning of these terms and provides an additional ground for advocating a broad interpretation. ${ }^{237}$

These instances suggest that legislative history can be useful even in circumstances where it fails specifically to resolve the meaning of a term. The use of legislative history in these instances would permit the court to anchor its choices on an informed understanding of parliamentary goals and concerns. But the bulk of the decisions, inconsistent with legislative history or made questionable by it, narrow the scope of the legislation. In this

233. 893 PARL. Deb., H.C. (5th ser.) 1491 (June 18, 1975). Also, in the debate, an opponent of the provision used the term "criteria" interchangeably with the terms "requirement" or "condition." Id. at 1492-93.

234. Id. The focus of these terms was to avoid indirect discrimination where a much smaller number of women than men could comply with such requirements. In the initial draft. "unfavorable condition or requirement" indicated the variety of employment circumstances that could disadvantage women. Id.

235. In first introducing Clause 1 of which this language was part, the Minister stated:

When we set about the preparation of this Bill we had to answer two basic questions. The first was: what kind of discrimination should be outlawed? The second question was: how should the law be enforced? . . . We decided that the net of the Bill should be wide and that the mesh of the bill should be fine. ...

It is that the unintended discrimination may be so deeply entrenched or so overwhelmingly effective that it is practically invisible and, therefore, may not give rise to any single individual complaint.

893 PARL. DEB., H.C. (5th ser.) 1429-30 (June 18, 1975).

236. E.g., John Gardiner, Section 20 of the Race Relations Act 1976: "Facilities" and "Services," 50 MOD. L. REV. 345 (1987) (critical of the House of Lords decisions defining these terms).

237. 374 PARL. DEB., H.L. (5th ser.) 762 (Oct. 1, 1976) (conceivable that immigration officers in exercising their function provided a service or facility while believing immunity provision Section 4l(1)(c) protected them); PARL. DEB., H.C., OfFICIAL REPORT, STANDING COMM. A, 478 (May 27, 1976) (comments to similar effect). 
sense, plain-meaning interpretation seems likely to produce a more narrow interpretation than would an approach which uses legislative history.

It bears noting that not all judicial opinions under the Acts are rendered doubtful by an inspection of the pertinent legislative history. Consider four examples in which legislative history clarifies or confirms interpretations reached by the courts.

In applying the Sex Discrimination Act, the court in Brennan v. J.H. Dewhurst Ltd. struggled with the meaning of the term "arrangements." 238 In Brennan, the person who made arrangements for the interviewing of candidates for a butcher's position did nothing to violate the law, but the person who conducted the interviews did violate the law. The defendant confronted the court with the distinction between making arrangements, that is, establishing the guidelines and delegating authority, and carrying out the arrangements. He suggested that the first was covered by the language of the Act, but that the second was not. The court rejected this interpretation, relying on the general purpose of the legislation. ${ }^{239}$

The legislative history confirms the court's interpretation by addressing the issue specifically. A person speaking for the government rejected amendments that would have limited the meaning of "arrangements," emphasizing that "the word, 'arrangements,' has been deliberately used to cover a large number of situations-not all of which we can envisage at this moment, but that is why we have chosen a wide ranging word like 'arrangements.' "240

The opinions discussed above also reflect the need to define "can comply."241 Although courts rejected a narrow, literal interpretation as inconsistent with the purpose of the Acts, they encountered confusion in structuring a definition that satisfied the purpose of these Acts in a variety of contexts. The broad definition, "can comply in practice," itself introduced additional ambiguities.

The legislative history supports a broad meaning of the term, but it also makes clear that the application of the term may vary in each case. The

238. 1983 I.R.L.R. 357 (E.A.T.).

239. Id. at 360 . The alternative interpretation would leave a gap in the Act and should be rejected when taking "into account the manifest policy of the Act as stated in the long title to the Act." Id.

240. Parl. Deb., H.C., Official Report, Standing Comm. B 107 (Apr. 24, 1975).

To summarize what I was saying, I ask the Committee to reject the Opposition amendment because in one sense it is restrictive, in that it would catch only interviewing arrangements and not all the arrangements which are made in respect of selection for jobs, and in the restrictive sense $I$ think it is bad.

Id. at 109 (Apr. 29, 1975) (statement of Mr. John Fraser, Under-Secretary of State for Employment). The amendment was rejected. Id. at 110.

241. See supra text accompanying notes 132-38. 
legislative history captures this broad, yet flexible, meaning as follows: "It will be understood by the courts and tribunals that the words 'can comply' in the Bill mean 'can reasonably be expected to comply." "242

To cite another example, the Acts require, with certain exceptions, that actions regarding discrimination in employment be brought before an industrial tribunal within three months of the alleged discrimination. The courts applied the three-month provision rigidly. ${ }^{243}$ Although one could argue that such an approach undermined the general purpose of the Acts, the legislative history would assure a court that Parliament also perceived the need to have a precise limitation period. While recognizing that too short a limitation period unjustly penalizes the employee, Parliament believed that it is necessary "to draw things fairly tightly so that recollection is not dimmed and remedy is not wrongly cut off by the passage of time."244

Finally, courts had little difficulty concluding that providing a mortgage subsidy for male employees of a business while denying the subsidy to female employees violated the Act. ${ }^{245}$ The legislative history demonstrates that Parliament believed likewise. Indeed, the possibility of discrimination regarding mortgage subsidies for employees appears specifically in the legislative history..$^{246}$

These four examples show that the legislative history is useful even when it confirms a judicial interpretation reached on other grounds. The legislative history can reduce uncertainty, eliminate further contention about an interpretation, and clarify ambiguity. This function of the legislative

242. PARl. Deb., H.C., Official Report, Standing Comm. B, 73 (Apr. 24, 1975) (statement of Mr. John Fraser, Under-Secretary of State for Employment).

243. Calder v. James Finlay Corp., 1989 I.R.L.R. 55, 56 (E.A.T.) (noting position of Industrial Tribunal). The nature of the deadlines is also illustrated by the litigation addressing at what point the alleged violation of the Acts occurred. Barclays Bank plc v. Kapur, [1991] 1 All E.R. 646, (H.L.); Sougrin v. Haringey Health Auth., 1992 I.R.L.R. 416 (C.A.) (discussing whether the violation extended over a period of time). In addition, industrial tribunals have the discretion to extend the deadline in appropriate cases. An industrial tribunal has considerable discretion in making this decision. See supra text accompanying note 63.

244. Parl. Deb., H.C., OfFicial Report, Standing Comm. A, 694 (June 22, 1976) (statement of Mr. Bryhmor John, Minister of State, Home Office) (indicating that a longer time limit would "hopelessly complicate matters."). Commenting on the assertion that the period would be too short, the person speaking for the government suggested that three months would be about the right balance between the complainant's ability to discover information and the protection of the interests of employers. Id.

245. E.g., Calder v. James Finlay Corp. Ltd., 1989 I.R.L.R. 55, 56 (E.A.T.).

246. PARL. DEB., H.C., OfFICIAL REPORT, STANDING COMM. B, 139-40 (Apr. 29, 1975) (statement of Mr. John Fraser, Under-Secretary of State for Employment) (noting that female employees would be discriminated against if concessionary rates of mortgages were provided to male but not female employees); 374 PARL. DEB., H.L. (5th ser.) 144 (Sept. 27, 1976) (statement of Lord Jacques, made during the debate of the Race Relations Act) (gives as an example of "other benefits" "preferential terms for mortgages"). 
history can vary in importance depending on the difficulty of the interpretive problem before the courts. This is precisely why the legislative history gives more significant reassurance in the first two examples than in the others: the first two were more contentious.

Of course, the legislative history does not address every issue with which the courts must deal. Some of these unresolved issues focus not necessarily upon specific terms of the statute but upon assessments of its general policies. Two examples from the Sex Discrimination Act are (1) whether the Act covers discrimination on the basis of pregnancy, and (2) whether it covers sexual harassment. ${ }^{247}$ Neither of these issues concerns the meaning of a specific term in the statute, but each involves judgments about the underlying policies of the Act. The legislative history of the Sex Discrimination Act of 1975 fails to address either issue; the few references to pregnancy provide little assistance, and sexual harassment is not mentioned. ${ }^{248}$

Under the English rules, the courts have been left to resolve these issues in light of the statutory language. Although some courts have concluded that discrimination on the basis of pregnancy is not covered, others have concluded that pregnancy is covered by the Sex Discrimination Act when, consistent with the statute, a man in roughly an equivalent position can be identified. ${ }^{249}$ Likewise, some opinions have concluded that sexual harassment is not covered by the Sex Discrimination Act; yet other opinions have disagreed, determining that sexual harassment is covered, but only to the extent that specific employment actions have been taken against the employee. ${ }^{250}$ Still other courts have found that a single instance of harassment, if serious enough, could constitute discrimination. ${ }^{251}$ Relying solely on the language and judicial conclusions regarding purpose, these opinions risk excluding coverage; and in parsing the legislative language,

247. See supra text accompanying notes $77,127-31$.

248. E.g., Parl. Deb., H.C., Official Report, Standing ComM. B, 90 (Apr. 24, 1975) (discussing the context of discrimination on the basis of marriage-comparing an unmarried woman with a child to an unmarried man with a child) (statement of Dr. Shirley Summerskill, Under-Secretary of State for the Home Department); id. at 234 (May 6, 1975) (In response to a question as to why special treatment to women in connection with pregnancy or childbirth did not violate provisions relating to the constabulary, Mr. John Fraser, speaking for the government, stated, "I think it is because men do not become pregnant.").

249. See supra text accompanying notes 127-31. See McGinley, supra note 124, at 419 (suggesting that the unwillingness of the courts to see discrimination against pregnant women as gender-based is "vindication[ ] of stereotyped views.").

250. McGinley, supra note 124, at 426-27 (suggesting that many English opinions fail to recognize hostile-environment cases of sexual harassment).

251. Bracebridge Engineering Ltd. v. Darby, 1990 I.R.L.R. 3, 4 (E.A.T.) (emphasizing that one instance of sexual harassment, if severe, can constitute violation of the Act but finding that employees involved in the incident were subject to disciplinary supervision). 
courts limit the scope of coverage. No protection is provided for pregnant women unless a similar situation involving a man can be articulated, while with sexual harassment, many opinions seem to exclude hostile environment cases that do not involve some formal aspect of employment status.

In these instances, it is difficult to determine what the influence of legislative history might be. Of course, the legislative history would still leave the courts with the limitations of the statutory language; and the use of legislative history is no guarantee that a broader interpretation would be adopted. Yet the legislative history does contain a perspective more likely to support a broad, rather than a narrow, interpretation. In this sense, the legislative history could inform judicial analysis by educating judges regarding the values and purposes underlying the legislation. ${ }^{252}$ Legislative history could balance the stereotypes and biases arising from plain-meaning interpretation. In fact, legislative history often shows that Parliament sought to alter those very stereotypes. The power of legislative history to educate regarding purpose is as significant as its power to direct a specific interpretation.

In short, an examination of the legislative history of the sex and race discrimination statutes demonstrates that use of the legislative history could have influenced significantly the judicial opinions that interpreted these statutes. In several important instances, use of the legislative history could have altered the interpretation of statutory terms. In other instances, the legislative history would have confirmed or clarified judicial interpretations. In still other instances, the legislative history could have changed judicial perceptions regarding approaches to interpretation and the purposes and goals of the statutes.

An examination of the legislative history also allows informed speculation regarding the influence that English rules could have on the

252. This use of legislative history relates to what Ronald Dworkin describes as the "coherence theory" of legislation, which "supposes that a statute should be interpreted to advance the policies or principles that furnish the best political justification for the statute." Dworkin, supra note 65 , at 41 . Distinguishing between legislative purpose and legislative motive captures much the same idea. See Breyer, supra note 4.

The exclusion of legislative history causes attention to be focused on individual terms and deprives the courts of a basis for more expansive interpretation based on the purposes of the statute. One commentator, comparing the approach of the English and American courts in interpreting civil rights legislation, said of American courts:

[T]hose courts concern themselves almost exclusively with interpretation of statute[s]. They do not see that task as one of subtle linguistic analysis, nor do they locate statutes in relation to pre-existing legal rules. Rather they treat major statutes as blueprints of social policy. . . . The legislation created a muscular skeleton, but the courts at all levels have put on the substantial flesh.

Barry Fitzpatrick, Racial Inequality and the Limits of Law, 49 MOD. L. REV. 68, 74-75 (1986). 
legislative process. Evidence of this influence comes principally from members of Parliament.

\section{B. The Influence on the Legislative Process}

That relying on legislative history to interpret statutes has deleterious effects on the legislative process is among those criticisms stressed by plainmeaning advocates. Among these supposed effects is the encouragement of sloppy drafting by legislators who could rely on legislative history rather than on statutory language to convey meaning.

The legislative history of the sex and race discrimination statutes supports the conclusion that the use of legislative history may influence the legislative process. The legislative history documents an emphasis on statutory drafting. In both Standing Committees and the debates in the House of Commons and the House of Lords, members of Parliament gave detailed consideration to the language of individual clauses of the Acts. ${ }^{253}$

Members of the Standing Committees appear to have had access to Notes on Clauses explaining the meaning of each clause. ${ }^{254}$ With these Notes, members addressed a number of drafting problems. ${ }^{255}$ Moreover, ministers were seen as having a duty to respond to concerns about ambiguity or confusion existing in the draft presented to the committee or to either House. ${ }^{256}$ This emphasis on drafting seems to have been motivated by the

253. The legislative history of both the committee deliberations in the House of Commons and the floor debates in the House of Commons and in the House of Lords shows a careful and detailed discussion of the legislation, often clause by clause.

254. The committees had access to the Notes on Clauses. This assumption rests upon the character of the questioning regarding the meaning of the individual clauses and upon a statement in the legislative history showing access to this material during consideration of the Race Relations Act of 1976. PARL. Deb., H.C., OfFICLAL REPORT, STANDing COMM. A, 321 (May 18, 1976) ("I apologise for detaining the Committee, but I am reminded of an important point by the notes on clauses which the minister has been kind enough to furnish to us.").

255. E.g., PARL. DEB., H.C., OfFicial RePORT, STANDING COMM. B, 7-8, 21-22, $28-$ 30, 54 (Apr. 22, 1975); id. at 83-87 (Apr. 24, 1975); id. at 146, 158-59 (Apr. 29, 1975); Parl. Deb., H.C., Official Report, STANDing CoMm. A, 56-57, $61-63$ (Apr. 29, 1976); id. at 138 (May 4, 1976); id. at 199 (May 11, 1976); id. at 477-81 (May 27, 1976).

256. Where a Member raises a point which appears to be obscure, or uncertain, or ambiguous, I should think if the House or Committee has the opinion that the criticism has merit, it would be the duty of the Minister in charge of the Bill to see that the matter was put right, so that the provision should be properly spelled out.

374 PARL. DEB., H.L. (5th ser.) 553-54 (Sept. 29, 1976) (statement of the Lord Chancellor). The legislative history demonstrates that ministers accept, and that members expect, this obligation. Parl. Deb., H.C., OfFicial RePORT, Standing ComM. A, 110 (May 4, 1976) (Minister notes obligation to look seriously at all points raised in committee.); id. (May 11, 1976) (Minister states that the government will make amendments based on comments of committee members.); PARl. Deb., H.C., Official RePORT, Standing COMM. B, 12 (Apr. 
need to provide clarity of language for those subject to the law and for accurate judicial interpretation.

It could be argued that the rejection of legislative history would make legislative bodies more sensitive to the language of provisions. ${ }^{257}$ The legislative history, however, contains strains of opinion inconsistent with this argument.

The legislative history reveals a number of concerns about judicial interpretation. Such concerns range from statements regarding the inability of courts to interpret statutory provisions as Parliament intended, ${ }^{258}$ to a reference that courts evade unpopular provisions through interpretation. ${ }^{259}$ These concerns led to calls not only for better drafting but also for judicial access to legislative history. ${ }^{260}$

These anxieties regarding judicial interpretation are accompanied by criticisms directed toward the drafting of the two pieces of legislation.

22,1975 ) (need for minister to respond to the concerns of committee members).

257. This attention to detail rests principally upon the performance of the legislative duties of Parliament. It is likely that such attention would be paid even if the courts used legislative history. The attention to detail, however, combined with references to the need for clarity to aid interpretation, permits the conclusion that Parliament's knowledge that the courts would not look to legislative history played some role in the legislative process. This role is not entirely a positive one. See infra note 263.

258. E.g., 905 PARL. DEB., H.C. (5th ser.) 1551 (Mar. 4, 1976) (Previous judicial interpretation left gap in the law.); id. at 1556 (Parliament must act to declare what the law ought to be in light of judicial interpretation of what the law is.); 362 PARL. DEB., H.L. (5th ser.) 157 (July 1, 1975) ("But no, my Lords, we create a profession that interprets legislation in the way they want it interpreted, and very often it is not the interpretation which the Government intended in the first place."); 361 PARL. DEB., H.L. (5th ser.) 1422 (칠 17, 1975) (concern about whether the courts will interpret the language of the Sex Discrimination Act reasonably); id. at 1179 (anxiety about leaving the interpretation to the courts); PARL. DEB., H.C., OFFICIAL REPORT, STANDING COMM. B, 31 (Apr. 22, 1975) (“All we are doing is to give the judges the parameters within which to exercise their discretion. These parameters are very generous, because if they were too narrow it would be possible for more narrow-minded-more, shall I say, traditionally-minded, male judges-to interpret them rather overstrictly.").

259. E.g., 905 PARL. DEB., H.C. (5th ser.) 613 (Oct. 27, 1976) (Discussing discovery provision of Race Relations Act, an opponent of the legislation stated, "[t]he clause goes far beyond anything known in the law of England. It is a disgrace. The judiciary finds it intolerable and consequently it has evaded it.").

260. Calls for judicial access to legislative history contained two suggestions. One was that the comments of ministers giving the meaning of a provision be included in the statute. 374 Parl. Deb., H.L. (5th ser.) 551 (Sept. 29, 1976). The Lord Chancellor believed this suggestion would clutter the statute with "gloss" in many instances where it was unnecessary. Id. at 552. The House of Lords now permits the courts to examine these statements when they would resolve an ambiguity in the language of the statute. See supra note 15 . The other suggestion was that each clause in the legislation be accompanied by marginal notes that explained what was meant. PARL. Deb., H.C., OfFiCial RePORT, STANDING COMM. B, 138 (Apr. 29, 1975) (suggestion of the minister in charge of the legislation). 
Because drafting lies primarily in the hands of civil servants of the ministry, which is responsible for the development of the legislation, these criticisms sometimes reflect that the competency of these individuals is being viewed with skepticism. ${ }^{261}$

Most important, the legislative history, particularly the remarks of ministers of the government, highlights the impossibility of parliamentary compliance with the standards of drafting imposed by the judicial rules of interpretation. Ministers stress that Parliament can neither address every conceivable detail nor envision all the circumstances in which the statutory language will apply. They further note Parliament's inability to catalogue every possible interplay of statutory language and terms ${ }^{262}$ or to explain adequately the broader goals and purposes of the legislation. Plain-meaning interpretation requires a language that Parliament cannot speak; and by rejecting legislative history, courts refuse to hear a language Parliament can effectively use.

The judicial opinions examined above support the view that Parliament

261. Pari. Deb., H.C., Official Report, Standing Comm. A, 176 (May 6, 1976) ("The minister has established a sympathetic rapport with this side of the Committee by acknowledging that he sometimes finds Civil Service drafting obscure. We take the point ... that gobbledegook is the appropriate word to apply."); PARL. DEB., H.C., OfFICIAL REPORT, STANDING COMMITTEE B, 8 (Apr. 22, 1975) (government amendments drafted in "legalese jargon" "serving only to confuse and mislead those whose job it will be at ground level to interpret it"). Of course, some of these criticisms may reflect disagreement regarding substance, as one minister has suggested. PARL. DEB., H.C., OFFICIAL REPORT, STANDING COMM. A, 177 (May 6, 1976) (ministerial statement).

Others have been critical of the drafting of these civil servants. Rawlinson, supra note 7 , at 283-84 (quoting Lord Hailsham, who described them as "very dedicated and talented" but further stated that "none of them has probably ever conducted a case at law and certainly none of them has ever tried one." Judicial criticism of the drafting of the legislation is not unknown. E.g., Dr. Banai v. Canadian High Comm'n, E.A.T./65/90 (1990) (transcript) ("[S]ection 8 is not happily drafted.") (also referring to criticism of the same section in Deria v. General Counsel of British Shipping, 1985 I.C.R. 847); Tower Hamlets London Borough Council v. Qayyum, 1987 I.C.R. 729, 731 (E.A.T.) (Section 1(1)(b) "excessively and unnecessarily convoluted").

262. E.g., 374 Parl. Deb., H.L. (5th ser.) 444 (Sept. 29, 1976) ("There comes a point when you have to be prepared to leave it to the courts or to the tribunal. It is quite impossible for Parliament to deal with every detail of the law.") (ministerial statement); PARL. DEB., H.C., OfFICIAL REPORT, STANDING COMM. A, 409 (May 25, 1976) ("As I said earlier, the language used in statutes is not one of mathematical precision and never can be. The judges have recognised that. That is why when Bills become law we rely for their effect upon judicial interpretation.") (ministerial statement); id. at 515 (June 8, 1976) (The discussion shows "how difficult it is to devise any form of words which may be included in a statute, as opposed to being put in a White Paper, to perform the twin tasks of being a genuine fulfillment of people's aspirations without exciting more disappointment than benefit in the result.") (ministerial statement); PARL. Deb., H.C., Officlal RePORT, Standing COMM. B, 13 (Apr. 22,1975 ) (difficulty of containing a policy in precise statutory language) (statement of a committee member). 
cannot remove every ambiguity. Careful drafting simply does not eliminate the need for interpretation; and perhaps it does not even significantly reduce the likelihood of judicial misunderstanding of statutory provisions. Overall, the lesson of the opinions interpreting the sex and race discrimination statutes is that even careful drafting leaves a large number of interpretive problems. Indeed, legislative anxiety about restrictive judicial interpretation motivated efforts at comprehensiveness that obscured, rather than clarified, meaning. ${ }^{263}$

\section{CONCLUSION}

To date, much of the debate regarding the use of legislative history has been both abstract and general. This debate, however, contains a variety of compelling and subtle arguments. Some of it relies on the experience or example derived from the use of legislative history in the interpretation of a number of different statutory provisions. Those who argue in favor of using legislative history point to the beneficial ways in which it has been used, while those who advocate plain-meaning interpretation cite examples of the abuse of legislative history. Both supporters and critics of the use of legislative history are left with a vision of a world in which interpretation of statutes occurs without the use of legislative history. Generally, critics envision a paradise, while supporters see a less beatific vision. These visions, however, only reflect the generalities or examples that buttress each view.

Comparative analysis permits examination of plain-meaning interpretation in ways which are difficult within our own legal system. Within a legal system, such as ours, that relies on the use of legislative history, construction of an experiment that tests the implications of statutory interpretation without legislative history poses a daunting challenge.

263. The immunity provisions of the Race Discrimination Act illustrate that the anxiety about how the courts would interpret some subsections led to the addition of a subsection which complicated judicial interpretation of the others. See supra text accompanying notes 177-91. The government believed that though the allocation of work permits by the Department of Employment was not covered by the Act, the courts might apply it to such allocation and that "[i]t would be manifestly quite wrong to leave this matter to the courts to decide." 374 PARL. DEB., H.L. (5th ser.) 762 (Oct. 1, 1976). The addition of the term "ethnic" seems in part motivated by restrictive judicial interpretation of the Race Relations Act of 1968. Also, there may be instances where Parliament includes unnecessary words in the legislation in order to avoid confusing the courts. E.g., 374 PARL. DEB., H.L. (5th ser.) 13940 (Sept. 27, 1976). There are hints in the legislative history that the sex discrimination statute may have been drafted more broadly and perhaps more vaguely than necessary in order to guard against restrictive judicial interpretation. PARL. DEB., H.C., OFFICIAL REPORT, STANDING COMM. B, 31 (Apr. 22, 1975). In the United States, one commentator argues that, to the extent judicial abandonment of legislative history discourages Congress from using the regular committee, floor debate, and conference process, "the technical quality of statutory law is likely to deteriorate significantly." Breyer, supra note 4 , at 873 . 
Comparative analysis, therefore, becomes necessary for achieving a thorough analysis of the implications of plain-meaning interpretation. Fortunately, the English system offers for observation the world envisioned by the critics of the use of legislative history. That world permits an empirical examination of a substantial body of decisions that interpret specific statutes. Such an examination demonstrates that comprehensive social legislation aimed at reform fares poorly in a world of plain-meaning interpretation. Although a number of caveats should always accompany comparative analysis, the evidence supporting this conclusion is nevertheless substantial and extensive.

This conclusion invites consideration of the ideological conflicts which form the background for the debate regarding the use of legislative history. The debate certainly appears to have an ideological component. Judicial advocates of plain-meaning interpretation include the most conservative justices on the United States Supreme Court-Justices Scalia, Kennedy, and Thomas. ${ }^{264}$ Judicial defenders of practices that allow more extensive use of legislative history include more liberal appellate judges such as Patricia Wald and Abner Mikva. 265

The initial attraction of plain-meaning interpretation rests on the ability of its advocates to link plain-meaning interpretation to judicial restraint and restrictions on the role of judges. This justification also plays the theme of popular sovereignty through the legislature. Restrictions on the courts are seen as the vindication of majoritarian democracy and appeal to a formalism that equates legality with clear standards contained within positive law.

Unfortunately, the examination of the English materials suggests that the opposite of these assertions is more likely the case. Plain-meaning interpretation can increase judicial discretion and enfeeble the legislature. Plain-meaning interpretation increases judicial discretion by freeing courts of the constraints imposed by the context that gave rise to the words used in statute. In interpreting those words, therefore, courts may roam through dictionaries, precedent, and social meanings which are attached to words but disconnected from the goals of the legislation. Plain-meaning interpretation also deprives the legislature of an essential language in explaining its meaning, a deprivation that acts to undermine the legislative process. Again, the evidence to support these conclusions is substantial and extensive.

In light of this evidence, plain-meaning interpretation is seen to obstruct legislative attempts at broad social change. Over time, plainmeaning interpretation will tend to narrow the scope of social legislation. Because plain-meaning interpretation necessarily draws on accepted or "common sense" meanings, it is inherently more conservative than 
legislation that seeks to alter the perspectives or practices underlying those meanings.

Because it denies the legislature a significant language that it can use to direct judicial interpretation, plain-meaning interpretation tends to limit the role of government. Extensive changes in the private sector, including the type attempted by social legislation, become more difficult; and because the implementation of policies may require modifying limitations on the scope of a statute imposed over a period of time, legislative efforts may falter short of implementing the goals of the original legislation if thwarted by plainmeaning interpretation. The ultimate failure of these legislative adjustments could arise from a variety of factors, which include insufficient political support to return to the issues, or simply changing or conflicting legislative priorities. In this sense, plain-meaning interpretation imposes a requirement for legislative majorities to be committed to specific reforms over a considerable period of time.

Plain-meaning interpretation does not neutrally and objectively implement the concepts of legislative authority and judicial restraint. Rather, it strongly reinforces the status quo, particularly as it hinders reform legislation, such as civil rights provisions. In this sense, adoption of plainmeaning interpretation involves ideological judgments, not technical questions.

Comparative analysis permits an evaluation of plain-meaning interpretation that is difficult within our own legal system. This evaluation shows that plain-meaning interpretation increases rather than limits judicial discretion, enfeebles rather than empowers the legislature, supports the status quo, and restricts legislative efforts at comprehensive social reform. Comparative analysis exposes the weaknesses of plain-meaning interpretation and reveals the close relationship between social reform, ideology, and judicial technique. 